From the Università di Palermo, Department of Oncology, Italy; University of Western Australia, Nedlands, Australia; University of Oxford, Department of Clinical Pharmacology, Oxford, United Kingdom; and Hôpital Tenon, Paris, France.

Submitted August 20, 2004; accepted May 9, 2005

Supported by Ministero dell'Instruzione dell'Universita e della Recerca/Pro-

grammi di Ricerca di Relevante Interes se Nazionale 2002 (prot. 2002068725);

Progetto Speciale 2000 Ministero Sanità (Grant No. 100/SCPS/4/18306) and grants from Associazione Italiana per la Ricerca sul Cancro.

Members of the TP53-CRC Collaborative Group are found in the Appendix.

Authors' disclosures of potential conflicts of interest are found at the end of this article.

Address reprint requests to Antonio Russo, MD, Via Veneto 5, 90144

Palermo, Italy; e-mail: Lab-oncobiologia@ usa.net or molecularoncology@yahoo.it.

() 2005 by American Society of Clinical Oncology

0732-183X/05/2330-1/\$20.00

DOI: $10.1200 / J C O .2005 .00 .471$

\title{
The TP53 Colorectal Cancer International Collaborative Study on the Prognostic and Predictive Significance of p53 Mutation: Influence of Tumor Site, Type of Mutation, and Adjuvant Treatment
}

Antonio Russo, Viviana Bazan, Barry Iacopetta, David Kerr, Thierry Soussi, and Nicola Gebbia, for the TP53-CRC Collaborative Study Group

$$
\begin{array}{llllllll}
\text { A } & \text { B } & \text { S } & \text { T } & \text { R } & \text { A } & \text { C } & \text { T }
\end{array}
$$

\section{Purpose}

The aims of the TP53 Colorectal Cancer (CRC) International Collaborative Study were to evaluate the possible associations between specific TP53 mutations and tumor site, and to evaluate the prognostic and predictive significance of these mutations in different site, stage, and treatment subgroups.

\section{Patients and Methods}

A total of 3,583 CRC patients from 25 different research groups in 17 countries were recruited to the study. Patients were divided into three groups according to site of the primary tumor. TP53 mutational analyses spanned exons 4 to 8.

\section{Results}

TP53 mutations were found in 34\% of the proximal colon tumors and in $45 \%$ of the dista colon and rectal tumors. They were associated with lymphatic invasion in proximal tumors. In distal colon tumors, deletions causing loss of amino acids were associated with worse survival. In proximal colon tumors, mutations in exon 5 showed a trend toward statistical significance $(P<.05)$ when overall survival was considered. Dukes' $C$ tumors with wild-type TP53 and those with mutated TP53 (proximal tumors) showed significantly better prognosis when treated with adjuvant chemotherapy.

\section{Conclusion}

Analysis of TP53 mutations from a large cohort of CRC patients has identified tumor site, type of mutation, and adjuvant treatment as important factors in determining the prognostic significance of this genetic alteration.

\section{J Clin Oncol 23. (C) 2005 by American Society of Clinical Oncology}

\section{INTRODUCTION}

In Western countries, cancers of the colon and rectum are second only to lung cancer both in terms of incidence and mortality. ${ }^{1}$ Although the mortality rate has declined in recent years, particularly for rectal cancer, the incidence continues to increase. Mutation of the TP53 tumor suppressor gene is thought to play an important role in the progression of colorectal cancer (CRC) and might therefore represent a clinically useful marker of prognosis. The frequency of
TP53 mutations in CRC is approximately 40\% to $50 \%$. $^{2}$ The majority (approximately $80 \%$ ) are missense mutations comprising GC to AT transitions at cytosine phosphate guanine dinucleotides and occur principally in five hotspot codons $\left(175,245,248,273\right.$, and 282). ${ }^{3}$ Most TP53 mutations occur in exons 5 to 8 , in highly conserved areas, and in three principal structural domains of the TP53 protein (L2, L3, and loop-sheet-helix [LSH]).,

Several groups have reported that different types of TP53 mutation are differentially 
associated with CRC prognosis. These include mutations in exon $7,{ }^{6}$ codon $245,{ }^{7}$ conserved areas, ${ }^{8}$ and the L3 structural domain. ${ }^{5,9}$ Results between groups have not always been consistent, however, and this is likely to reflect the insufficient statistical power of individual studies. Several important issues should be considered when evaluating the prognostic significance of TP53 mutations in CRC. First, loss of TP53 function is a late event in adenoma-carcinoma progression. ${ }^{10,11}$ Second, TP53 mutations have a different incidence and perhaps also prognostic impact depending on the site of origin of the tumor in the large bowel. The frequency of TP53 mutations is higher in distal colon and rectal tumors than in proximal colon tumors. ${ }^{12,13}$ Third, different frequencies of individual TP53 mutations between populations may also account for previous discordant results on the prognostic significance of this genetic alteration.

Furthermore, several clinical studies have reported that CRC patients with wild-type TP53 derive a survival benefit from fluorouracil (FU) -based chemotherapy but those with mutant TP53 do not. ${ }^{2}$ Hence, the prognostic impact of TP53 mutation should be evaluated separately for patients treated with or without adjuvant chemotherapy to avoid this interaction. The aim of the TP53-CRC International Collaborative Study was to pool data from a large number of individual studies to evaluate the prognostic and predictive significance of TP53 mutations in CRC according to site of origin in the large bowel, tumor stage, type of mutation, and use of adjuvant treatment.

\section{PATIENTS AND METHODS}

\section{Recruitment}

Beginning in September 2001, different research groups around the world were invited to participate in this International Collaborative Study. The selection of groups for contact was by means of a Medline search for publications on TP53 mutations and CRC. A Web page created within the site http:// www.p53.free.fr and entitled "TP53 Mutation Analysis in Colorectal Cancer: Call for an International Collaborative Study” was also used to alert research groups to the study. Appropriate groups identified by the Medline search received a formal invitation to participate in the study. If an affirmative answer was received, a questionnaire was sent for the collection of information required for the study. In all, 25 groups agreed to participate in the study and returned the completed questionnaires. Individual groups have published much of the data in this study previously. $9,13-33$ The names of the communicating authors from each group, their country of origin, and the number of patients contributed to the study are shown in Table 1.

\section{Information Requested by Questionnaire}

The information requested for each patient included patient age and sex, presence of predisposing factors, use of adjuvant therapies, and site of relapse, if any. Other information included the date of surgery, Dukes' stage, surgical outcome, and site of the primary tumor. Tumor site was classified as follows: proximal colon included cecum through to and including transverse colon
(Original Operations Details [OOD]-2 codes CP1, CP3), distal colon included splenic flexure through to and including the descending colon (OOD-2 code CP2), and rectal cancer group comprising the sigmoid colon and rectum (OOD-2 code CP4). Other information included the date of last follow-up or death (perioperative, cancer or unrelated to cancer), tumor type (flat or polypoid), histologic grade (well-differentiated [G1], moderately differentiated [G2], poorly differentiated [G3]), lymphocyte infiltration (prominent, not prominent), vascular invasion, mucinous status ( $0 \%$ to $50 \%,>50 \%$ ), lymphatic invasion, and regional lymph node involvement.

Information on the type of tissue was also requested (frozen or paraffin embedded) as well as the control tissue used (normal mucosa, blood, or other). Information on the methods used for mutational analysis of the TP53 gene were also requested, including polymerase chain reaction-single-stranded conformation polymorphism (PCR-SSCP), PCR-denaturing gradient gel electrophoresis (DGGE), PCR sequencing, or other.

Information on the type of TP53 gene mutation (point or frameshift) and site of mutation (codon, exon, functional domain, or conserved area) was also requested. For tumors with more than one mutation, the data for each is included as a separate entry. Where specific information was not available, this was entered in the database as not available.

\section{Patient Characteristics}

This collaborative study included data from a total of 3,583 CRC patients (from 17 different countries) with information on TP53 gene mutation status. Patients were divided into three groups according to site of the primary tumor: 1,017 (28\%) sites were proximal colon, $426(12 \%)$ were distal colon, and 2,031 (57\%) were sigmoid colon and rectum. For another 109 (3\%) patients, it was not possible to establish the site of the original tumor and hence these were not included in the analyses relating to tumor site. Table 2 shows the clinicopathologic features of the three patient groups classified according to site of tumor origin and includes patient age and sex; tumor size, stage, and grade; lymphatic and vascular invasion; and treatment with chemotherapy for the Dukes' C subgroup. Median follow-up times for patients were 58 months (range, 1 to 194 months), 61 months (range, 1 to 173 months), and 61 months (range, 1 to 235 months) for the proximal colon, distal colon, and rectal tumor groups, respectively. Additional information on patient and tumor characteristics from each of the contributing centers is shown in the Appendix, Supplementary Table.

\section{TP53 Mutation Screening Techniques}

TP53 mutational analyses spanned exons 4 to 8. Exon 4 was screened in 1,880 patients (53\%). For mutational analysis, 14 groups used frozen material for a total of 1,191 specimens (34\%), and nine groups used paraffin-embedded specimens for 1,878 specimens (52\%). Fresh tissue was used for 63 specimens $(1.7 \%)$, whereas the storage method was not specified for 514 specimens $(14 \%)$. Normal mucosa was used as the non-neoplastic control in $90 \%(3,243$ of 3,583$)$ of patients. A total of 2,397 patients were screened by PCR-SSCP followed by sequencing, 158 patients were screened by PCR-DGGE followed by sequencing, 281 patients were screened directly by DNA sequencing, 114 patients were screened by SSCP alone, and 454 patients were screened by temperature-gradient gel electrophoresis or DGGE alone. No information on the TP53 mutation screening technique was provided for 179 patients. 
Table 1. Groups Included in the TP53-CRC International Collaborative Study

\begin{tabular}{|c|c|c|c|c|c|c|c|c|c|}
\hline \multirow[b]{2}{*}{ Author } & \multirow[b]{2}{*}{ Country } & \multirow{2}{*}{$\begin{array}{l}\text { Total No. } \\
\text { of } \\
\text { Patients }\end{array}$} & \multicolumn{2}{|c|}{$\begin{array}{l}\text { TP53 Mutation } \\
\text { Frequency }\end{array}$} & \multicolumn{2}{|c|}{$\begin{array}{c}\text { Patients for } \\
\text { Survival } \\
\text { Analyses }\end{array}$} & \multirow{2}{*}{$\begin{array}{l}\text { Median } \\
\text { Follow-Up } \\
\text { (months) }\end{array}$} & \multirow{2}{*}{$\begin{array}{l}\text { Patients for } \\
\text { Clinical and } \\
\text { Pathologic } \\
\text { Associations }\end{array}$} & \multirow{2}{*}{$\begin{array}{l}\text { Patients } \\
\text { With } \\
\text { Unknown } \\
\text { Tumor } \\
\text { Site }\end{array}$} \\
\hline & & & No. & $\%$ & No. & $\%$ & & & \\
\hline lacopetta et $\mathrm{al}^{14}$ & Australia & 1,135 & 406 & 36 & 1,090 & 97 & 82 & 1,121 & 14 \\
\hline Kandioler et $\mathrm{al}^{15}$ & Austria & 74 & 53 & 71 & 71 & 97 & 35 & 73 & 1 \\
\hline Lung et al ${ }^{16}$ & China & 99 & 35 & 35 & 16 & 16 & 9 & 97 & 2 \\
\hline Yuen et al ${ }^{17}$ & China & 67 & 29 & 43 & 66 & 98 & 89 & 67 & 0 \\
\hline Crapez et alt & France & 91 & 33 & 36 & 87 & 96 & 48 & 91 & 0 \\
\hline Leahy et al ${ }^{18}$ & Ireland & 66 & 27 & 41 & 66 & 100 & 121 & 66 & 0 \\
\hline Chieco-Bianchi et al ${ }^{19}$ & Italy & 335 & 139 & 41 & 0 & & NA & 329 & 6 \\
\hline Giaretti et $\mathrm{al}^{20}$ & Italy & 60 & 35 & 58 & 13 & 23 & 31 & 56 & 4 \\
\hline Ricevuto et alt & Italy & 44 & 18 & 41 & 43 & 100 & 89 & 43 & 1 \\
\hline Russo et $\mathrm{al}^{9}$ & Italy & 160 & 68 & 43 & 160 & 100 & 71 & 160 & 0 \\
\hline Miyaki21 & Japan & 58 & 34 & 59 & 0 & 45 & NA & 57 & 1 \\
\hline Onda ${ }^{22}$ & Japan & 45 & 27 & 60 & & 100 & 98 & 45 & 0 \\
\hline Kampman ${ }^{23}$ & Netherlands & 184 & 57 & 31 & 140 & 81 & 55 & 172 & 12 \\
\hline Lothe et $\mathrm{al}^{24}$ & Norway & 221 & 100 & 45 & 218 & 99 & 63 & 221 & 0 \\
\hline Guzinska et al & Poland & 47 & 21 & 45 & 43 & 91 & 34 & 47 & 0 \\
\hline Ostrowski et al ${ }^{25}$ & Poland & 50 & 23 & 46 & 48 & 96 & 58 & 50 & 0 \\
\hline Capella et $\mathrm{al}^{26}$ & Spain & 163 & 81 & 50 & 161 & 99 & 18 & 163 & 0 \\
\hline Lonnroth/Lundholm K et al ${ }^{27}$ & Sweden & 98 & 37 & 38 & 93 & 99 & 103 & 94 & 4 \\
\hline Sun et $\mathrm{al}^{28}$ & Sweden & 75 & 41 & 55 & 71 & 94 & 176 & 73 & 0 \\
\hline Bouzourene et $\mathrm{al}^{29}$ & Switzerland & 123 & 39 & 32 & 122 & 99 & 64 & 123 & 0 \\
\hline Hsieh et $\mathrm{al}^{30}$ & Taiwan & 182 & 57 & 31 & 180 & 99 & 96 & 182 & 0 \\
\hline Smith ${ }^{13 *}$ & Thailand & 53 & NA & & 0 & & NA & 0 & 53 \\
\hline Allan-Mersh et $\mathrm{al}^{31}$ & United Kingdom & 20 & Not assessableł & & 11 & 100 & 34 & 11 & 9 \\
\hline Royds et $\mathrm{al}^{32}$ & United Kingdom & 19 & 16 & 84 & 19 & 100 & 52 & 19 & 0 \\
\hline Bosari and Silverman ${ }^{33}$ & United States & 114 & 65 & 57 & 112 & 98 & 75 & 114 & 0 \\
\hline Total & & 3,583 & & & 2,875 & 80 & 3,474 & 109 & \\
\hline
\end{tabular}

Abbreviation: NA, not available.

*No information given on primary site of tumors.

†Unpublished data.

‡This group supplied information only for patients with p53 mutation.

\section{Definition of TP53 Mutation Types}

The analyses involved consideration of any TP53 mutation, mutations specific to exons 4 to 8 , and those in regions coding for the main functional and structural domains of the protein. These included the L2 loop (codons 163 to 195), L3 loop (codons 236 to 251), LSH motif (codons 271 to 286) as well as the highly conserved areas II (codons 117 to 142), III (codons 171 to 181), IV (codons 234 to 258), and V (codons 270 to 286). ${ }^{34}$ Mutations in the hotspot codons were also examined (codons 175, 196, 213, 245, 248, 249, 273, and 282), as well as those in the denaturant codons known to have a direct effect on TP53 stability (codons 143, 175, 245, 249, and 282), those in zinc-binding codons (codons 176, 179, 238, and 242), those involved with DNA interaction (codons 120, 241, 248, 273, 276, 277, 280, 281, and 283), and those involved in direct DNA contact (codons 248 and 282). 5,34 Analysis of point mutations (missense and nonsense), frameshift mutations (insertions and deletions), and transitions and transversions was performed. Finally, analysis of mutations that affect the following classes of amino acids was performed: polar neutral, apolar neutral, basic, and acid, together with the type of amino acid change according to the lateral group.

\section{Statistical Analysis}

Statistical analyses were performed separately for each of the three subgroups of patients classified according to the site of tumor origin. Associations between TP53 mutations (any or specific) and clinicopathologic variables were evaluated by the $\chi^{2}$ test with Yates correction, where appropriate. The relationship between different prognostic variables and overall survival (OS) was assessed univariately by the Kaplan-Meier method. Patients with no follow-up details $(n=708)$ were excluded from the OS analyses. Survival time was calculated from the date of surgery to the date of death (cancer-related causes) or last follow-up, with times censored for patients who died as a result of causes unrelated to CRC or perioperatively. Significant differences between survival curves were evaluated by the logrank and Wilcoxon tests, or a test for trend where appropriate. In view of the multiple statistical analyses performed, only values where $P<.01$ were considered significant. Multivariate analysis was carried out by means of the Cox proportional hazards model, using a backward procedure. ${ }^{35}$ Only the significant variables in univariate analysis were considered in the Cox model. All $P$ values were two sided. 


\begin{tabular}{|c|c|c|c|c|c|c|c|}
\hline \multirow[b]{2}{*}{ Characteristic } & \multicolumn{2}{|c|}{ Proximal Colon } & \multicolumn{2}{|c|}{ Distal Colon } & \multicolumn{2}{|c|}{ Rectum } & \multirow[b]{2}{*}{$P$} \\
\hline & No.* & $\%$ & No.* & $\%$ & No.* & $\%$ & \\
\hline Total No. & 1,017 & & 426 & & 2,031 & & \\
\hline \multicolumn{8}{|l|}{ Age, years } \\
\hline$<50$ & 82 & 8 & 42 & 10 & 264 & 13 & \\
\hline $50-75$ & 664 & 66 & 299 & 71 & 1,364 & 67 & \\
\hline$>75$ & 265 & 26 & 82 & 19 & 397 & 20 & $<.001$ \\
\hline Mean & \multicolumn{2}{|c|}{67.4} & \multicolumn{2}{|c|}{64.9} & \multicolumn{2}{|c|}{64.5} & \\
\hline$S D$ & \multicolumn{2}{|c|}{11.8} & \multicolumn{2}{|c|}{11.8} & \multicolumn{2}{|c|}{12.7} & \\
\hline Range & \multicolumn{2}{|c|}{$21-93$} & \multicolumn{2}{|c|}{$19-91$} & \multicolumn{2}{|c|}{$20-99$} & \\
\hline \multicolumn{8}{|l|}{ Sex } \\
\hline Male & 503 & 49 & 218 & 51 & 1,153 & 57 & \\
\hline Female & 512 & 51 & 207 & 49 & 877 & 43 & $<.001$ \\
\hline \multicolumn{8}{|l|}{ Size, $\mathrm{cm}$} \\
\hline$\leq 5$ & 147 & 49 & 92 & 69 & 509 & 72 & \\
\hline$>5$ & 153 & 51 & 41 & 31 & 197 & 28 & $<.001$ \\
\hline \multicolumn{8}{|l|}{ Type } \\
\hline Flat & 24 & 15 & 21 & 23 & 83 & 19 & \\
\hline Polypoid & 131 & 85 & 72 & 77 & 360 & 81 & NS \\
\hline \multicolumn{8}{|l|}{ Dukes' stage } \\
\hline A & 64 & 6 & 38 & 9 & 266 & 13 & \\
\hline B & 391 & 39 & 170 & 40 & 650 & 32 & \\
\hline C & 470 & 46 & 163 & 38 & 950 & 47 & \\
\hline $\mathrm{D}$ & 90 & 9 & 55 & 13 & 154 & 8 & $<.001$ \\
\hline Regional lymph nodes & & & & & & & \\
\hline NO & 419 & 48 & 209 & 54 & 802 & 49 & \\
\hline N1 & 253 & 29 & 106 & 28 & 504 & 31 & \\
\hline N2/N3 & 195 & 23 & 68 & 18 & 330 & 20 & NS \\
\hline Histologic grade & & & & & & & \\
\hline Well-differentiated (G1) & 139 & 14 & 79 & 19 & 283 & 15 & \\
\hline Moderately differentiated (G2) & 605 & 62 & 290 & 70 & 1,398 & 72 & \\
\hline Poorly differentiated (G3) & 236 & 24 & 44 & 11 & 255 & 13 & $<.001$ \\
\hline Lymphatic invasion & & & & & & & \\
\hline Present & 115 & 48 & 54 & 47 & 249 & 46 & \\
\hline None & 127 & 52 & 62 & 53 & 292 & 54 & NS \\
\hline Lymphocyte infiltration & & & & & & & \\
\hline Prominent & 43 & 24 & 48 & 53 & 124 & 37 & \\
\hline Not prominent & 133 & 76 & 43 & 47 & 212 & 63 & $<.001$ \\
\hline Vascular invasion & & & & & & & \\
\hline Present & 51 & 26 & 12 & 13 & 133 & 26 & \\
\hline None & 147 & 74 & 82 & 87 & 382 & 74 & NS \\
\hline Mucinous status & & & & & & & \\
\hline Not mucinous tumors $(0 \%-50 \%)$ & 229 & 84 & 103 & 88 & 583 & 93 & \\
\hline Mucinous tumors (> 50\%) & 44 & 16 & 14 & 12 & 42 & 7 & .022 \\
\hline Surgical resection & & & & & & & \\
\hline Apparently curative & 817 & 92 & 271 & 92 & 1,727 & 94 & \\
\hline No resection/residual tumor & 69 & 8 & 23 & 8 & 119 & 6 & NS \\
\hline Chemotherapy treatment ${ }^{\dagger}$ & & & & & & & \\
\hline Total & 470 & & 163 & & 950 & & \\
\hline Yes & 140 & 35 & 43 & 37 & 284 & 34 & \\
\hline No & 260 & 65 & 72 & 63 & 538 & 66 & NS \\
\hline $\begin{array}{l}\text { NOTE. In } 109 \text { patients, the site of } p \\
\text { for } 2,335 \text { patients, type was not knd } \\
\text { patients, histologic grade was not kn } \\
2,871 \text { patients, vascular invasion wa } \\
\text { for } 448 \text { patients, and chemotherapy } \\
\text { Abbreviation: CRC, colorectal cance } \\
\text { "The percentage of clinicopathologi } \\
\text { tDukes' C patients only; chemothe }\end{array}$ & $\begin{array}{l}\text { was un } \\
83 \text { patie } \\
5 \text { patier } \\
\text { h for } 2, \\
\text { n Duke } \\
\text { was cal } \\
\text { ent wa }\end{array}$ & $\begin{array}{l}\text { atic ir } \\
\text { ts, } m \\
\text { ot } k r \\
\text { ly for }\end{array}$ & $\begin{array}{l}\text { Nn for } \\
\text { ot knov } \\
\text { s not k } \\
\text { atus w? } \\
46 \text { pati } \\
\text { tients. } \\
\text { rapy in }\end{array}$ & $\begin{array}{l}\text { patie } \\
2,575 \\
\text { wn f }\end{array}$ & $\begin{array}{l}\text { known f } \\
\text { hal lymph } \\
\text { lymphoc } \\
\text { atients, }\end{array}$ & $\begin{array}{l}\text { ths, si } \\
\text { vere } \\
\text { ation } \\
\text { secti }\end{array}$ & $\begin{array}{l}\text { t known } \\
\text { h for } 588 \\
\text { nown for } \\
\text { t known }\end{array}$ \\
\hline
\end{tabular}




\section{RESULTS}

The 25 different groups that contributed data to this study on TP53 mutations in CRC are listed in Table 1. Raw data from individual studies are listed in the Appendix, Supplementary Table.

\section{Clinicopathologic Results}

Clinicopathologic data were analyzed according to the site of tumor origin in the large bowel (Table 2). In line with previous studies on CRC, rectal cancer patients were younger and more often male compared with proximal cancer patients. Rectal tumors were also smaller compared with proximal colon tumors. Proximal cancers were more often poorly differentiated and mucinous but showed less lymphocyte infiltration compared with rectal cancers. No site-related differences were apparent for the frequency of nodal involvement, vascular invasion, or the use of chemotherapy.

Using proximal colon cancer as the reference group, patients with distal colon cancer showed marginally better
OS (relative risk $[\mathrm{RR}]=0.82 ; 95 \% \mathrm{CI} 0.68$ to $1.00 ; P=.05$ ). No significant difference in OS was observed between proximal colon and rectal tumor groups. The OS of patient subgroups classified according to the site of tumor origin in the large bowel is listed in Table 3. For each tumor site, only the clinical features that show significant prognostic value are shown. As expected, advanced Dukes' stage, nodal involvement, poor histologic grade, lymphatic invasion, and noncurative resections were all associated with significantly worse survival.

\section{Relationship Between TP53 Mutations and Clinicopathologic Features}

The overall frequency of TP53 mutation in this CRC series was $42 \%(1,449$ of 3,474$)$. A significantly higher frequency of mutations $(P<.001)$ was found in distal colon and rectal tumors (both groups, $45 \%$ ) compared with proximal tumors (34\%; Table 4). TP53 mutations were associated with lymphatic invasion in proximal tumors and showed trends for association with advanced Dukes' stage (all sites) and with lymphatic (rectal

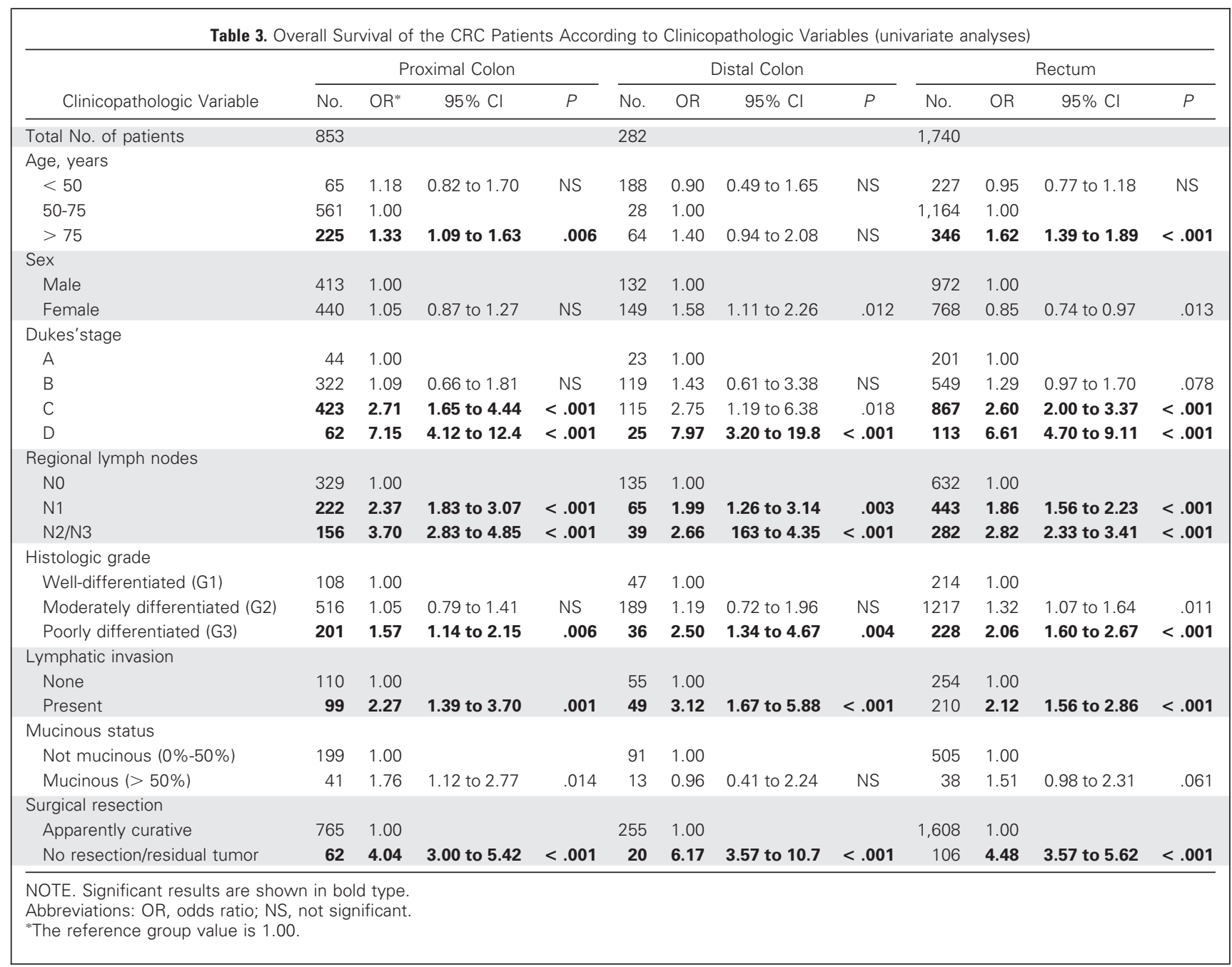




\begin{tabular}{|c|c|c|c|c|c|c|c|c|c|}
\hline \multirow[b]{2}{*}{$\begin{array}{c}\text { Clinicopathologic } \\
\text { Variable }\end{array}$} & \multicolumn{3}{|c|}{ Proximal Colon } & \multicolumn{3}{|c|}{ Distal Colon } & \multicolumn{3}{|c|}{ Rectum } \\
\hline & $\begin{array}{c}\text { TP53 } \\
\text { Mutation }\end{array}$ & $\%$ & $P$ & TP53 Mutation & $\%$ & $P$ & TP53 Mutation & $\%$ & $P$ \\
\hline All patients & 350 of 1,017 & 34 & & 191 of 426 & 45 & & 908 of 2031 & 45 & \\
\hline \multicolumn{10}{|l|}{ Dukes' stage } \\
\hline$A$ & 15 of 64 & 23 & & 11 of 38 & 29 & & 109 of 266 & 41 & \\
\hline B & 133 of 391 & 34 & & 72 of 170 & 42 & & 288 of 650 & 44 & \\
\hline C & 163 of 470 & 35 & & 79 of 163 & 49 & & 423 of 950 & 45 & \\
\hline $\mathrm{D}$ & 38 of 90 & 42 & $<.05$ & 29 of 55 & 53 & $<.05$ & 84 of 154 & 55 & $<.05$ \\
\hline \multicolumn{10}{|l|}{ Lymphatic invasion } \\
\hline None & 32 of 127 & 25 & & 22 of 62 & 35 & & 136 of 292 & 47 & \\
\hline Present & 49 of 115 & 43 & $<.01$ & 27 of 54 & 50 & NS & 140 of 249 & 56 & $<.05$ \\
\hline \multicolumn{10}{|l|}{ Vascular invasion } \\
\hline None & 18 of 147 & 12 & & 36 of 82 & 44 & & 182 of 382 & 48 & \\
\hline Present & 22 of 51 & 43 & NS & 9 of 12 & 75 & $<.05$ & 79 of 133 & 59 & $<.05$ \\
\hline
\end{tabular}

tumors) or vascular invasion (distal and rectal tumors; Table 4). None of the other clinicopathologic features (age, sex, size, or grade) showed significant associations with TP53 mutation frequency. Frameshift mutations were associated with lymphatic invasion in proximal tumors $(P<.01$; data not shown $)$, and in rectal tumors frameshift mutations showed trends for association with advanced Dukes' stage, and lymphatic and vascular invasion $(P<.05$; data not shown $)$.

\section{Mutation Analysis of the TP53 Gene}

The different types of TP53 mutations in this CRC cohort are shown in Table 5. Three hundred fifty (34\%) of the 1,017 patients with a proximal colon cancer had TP53 mutations, with 28 showing more than one mutation. Of these, seven had two mutations in one exon, 18 had two mutations in two exons, and three had three mutations, producing a total of 381 mutations identified. One hundred ninety-one $(45 \%)$ of the 426 patients with distal colon cancer had TP53 mutations, with 11 showing more then one mutation. Of these, seven had two mutations in one exon, three had two mutations in two exons, and one had three mutations in two different exons, for a total of 203 mutations identified. Finally, 908 (45\%) of the 2,031 patients with rectal cancer had a mutation in TP53, with 46 patients showing more than one mutation. Of these, 14 patients had two mutations in one exon, 29 had two mutations in two exons, and three had three mutations in two different exons, producing a total of 957 mutations identified. A remarkably similar profile for the type of TP53 mutation was observed for tumors from the three different sites, with no significant differences between sites observed for the frequency of any individual TP53 mutation type examined (Table 5).

\section{TP53 Mutations and Clinical Outcome}

TP53 mutations in the overall CRC cohort or in the three different tumor site groups did not show significant prognostic value (Table 6). Investigation of different types of TP53 mutations revealed some interesting associations, however, particularly for distal colon tumors. In this group, worse outcome compared with tumors with wild-type TP53 was observed for mutations in the LSH region, denaturing mutations, multiple mutations, or mutations yielding the same amino acid side group or an amino acid loss (Table 6). For proximal colon tumors, only TP53 mutations in exon 5 were significantly associated with worse survival; for rectal tumors, only those giving rise to an amino acid loss were significantly associated with worse survival. In multivariate analysis adjusted for Dukes' stage, nodal status, histologic grade, and lymphatic invasion, only TP53 mutation associated with an amino acid loss in distal colon tumors was an independent factor for worse survival ( $\mathrm{RR}=2.52 ; 95 \%$ CI, 1.28 to $4.93 ; P=.007)$. A trend toward statistical significance for worse outcome was also observed for exon 5 mutations in proximal colon tumors $(\mathrm{RR}=1.36$; 95\% CI, 1.03 to $1.79 ; P=.03$ ). Adjustment for study center revealed no significant differences in the odds ratio for survival for either TP53 mutation or Dukes' stage (results not shown).

\section{TP53 Mutations and Adjuvant Treatment}

The predictive significance of TP53 mutation in Dukes' $C$ patients treated with or without adjuvant chemotherapy is listed in Table 7. For patients with wild-type TP53, those treated with chemotherapy showed significantly better survival in proximal colon and rectal tumor groups, whereas a trend toward statistical significance $(P=.022)$ was observed for the distal colon tumors. For patients with 


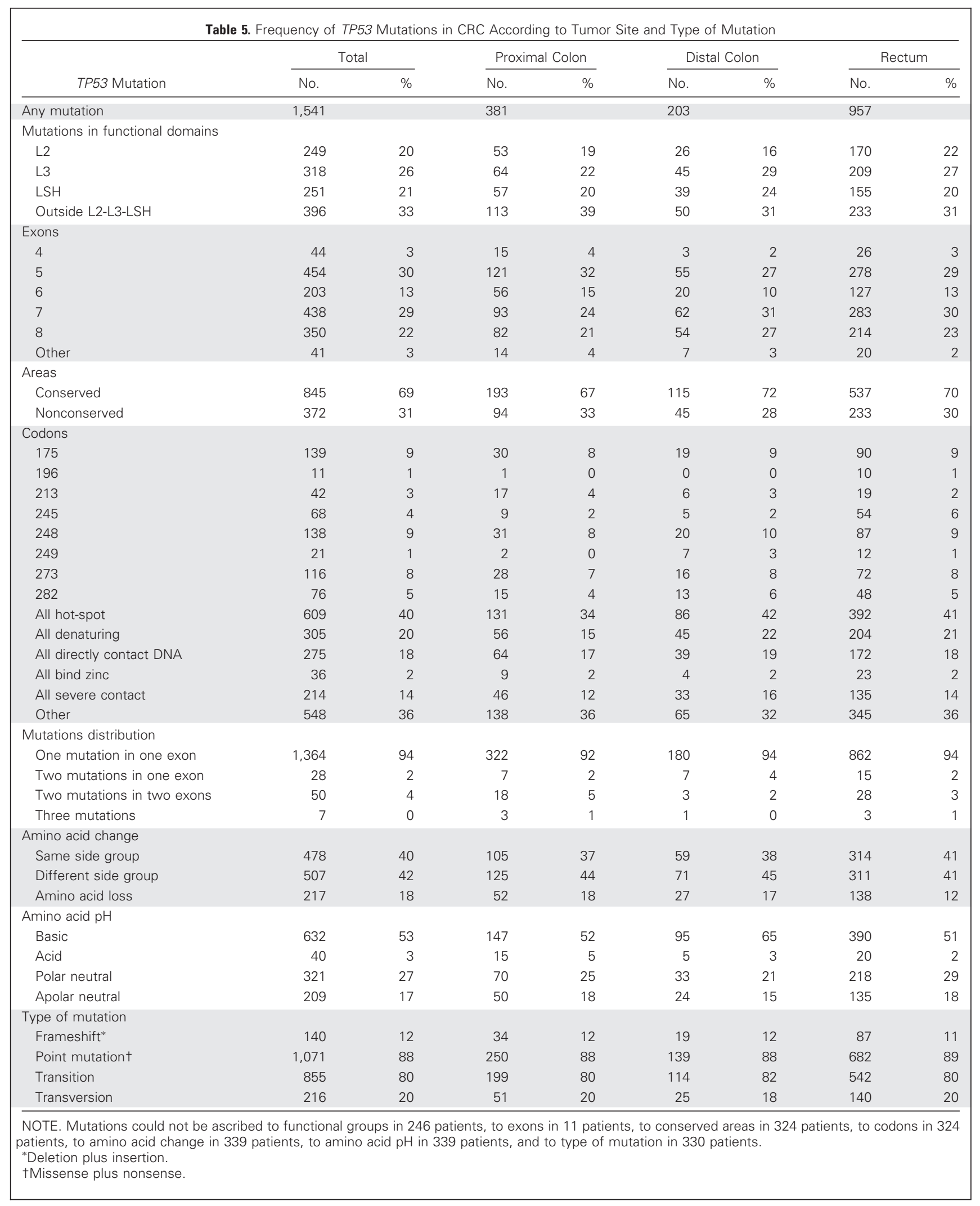




\begin{tabular}{|c|c|c|c|c|c|c|c|c|c|c|c|c|}
\hline \multirow[b]{2}{*}{ Type of TP53 Mutation } & \multicolumn{4}{|c|}{ Proximal Colon } & \multicolumn{4}{|c|}{ Distal Colon* } & \multicolumn{4}{|c|}{ Rectumt } \\
\hline & No. & OR & $95 \% \mathrm{Cl}$ & $P$ & No. & OR & $95 \% \mathrm{Cl}$ & $P$ & No. & OR & $95 \% \mathrm{Cl}$ & $P$ \\
\hline Total & 853 & & & & 282 & & & & 1,740 & & & \\
\hline \multicolumn{13}{|l|}{ TP53 mutations } \\
\hline WT & 563 & 1.00 & & & 164 & 1.00 & & & 968 & 1.00 & & \\
\hline Any mutations & 290 & 1.19 & 0.98 to 1.44 & .073 & 118 & 1.29 & 0.91 to 1.83 & NS & 772 & 0.97 & 0.85 to 1.11 & NS \\
\hline \multicolumn{13}{|l|}{ Functional domains } \\
\hline WT & 563 & 1.00 & & & 164 & 1.00 & & & 968 & 1.00 & & \\
\hline Mutation in L2 & 76 & 1.18 & 0.85 to 1.63 & NS & 21 & 0.96 & 0.44 to 2.10 & NS & 167 & 1.09 & 0.87 to 1.37 & NS \\
\hline Mutation in L3 & 38 & 1.50 & 0.99 to 2.27 & .058 & 15 & 1.29 & 0.62 to 2.70 & NS & 141 & 0.88 & 0.68 to 1.13 & NS \\
\hline Mutation in LSH & 51 & 1.08 & 0.72 to 1.61 & NS & 20 & 1.87 & 1.05 to 3.33 & .033 & 161 & 0.95 & 0.76 to 1.20 & NS \\
\hline Outside L2-L3-LSH & 46 & 0.80 & 0.51 to 1.26 & NS & 23 & 1.26 & 0.67 to 2.38 & NS & 136 & 0.88 & 0.69 to 1.13 & NS \\
\hline \multicolumn{13}{|l|}{ TP53 Exons } \\
\hline WT & 563 & 1.00 & & & 164 & 1.00 & & & 968 & 1.00 & & \\
\hline Exon 5 & 91 & 1.47 & 1.11 to 1.93 & .007 & 31 & 1.42 & 0.84 to 2.38 & NS & 224 & 0.98 & 0.80 to 1.19 & NS \\
\hline Other exons $(4,6,7,8)$ & 199 & 1.07 & 0.86 to 1.34 & NS & 86 & 1.24 & 0.84 to 1.83 & NS & 540 & 0.97 & 0.83 to 1.12 & NS \\
\hline \multicolumn{13}{|l|}{ Site of TP53 mutations } \\
\hline WT & 563 & 1.00 & & & 164 & 1.00 & & & 968 & 1.00 & & \\
\hline Denaturing & 47 & 1.16 & 0.76 to 1.76 & NS & 21 & 2.22 & 1.27 to 3.90 & .005 & 177 & 0.94 & 0.75 to 1.18 & NS \\
\hline Other mutations & 163 & 1.10 & 0.86 to 1.40 & NS & 58 & 1.83 & 0.69 to 1.72 & NS & 439 & 0.96 & 0.82 to 1.12 & NS \\
\hline \multicolumn{13}{|l|}{ TP53 mutation distribution } \\
\hline WT & 563 & 1.00 & & & 164 & 1.00 & & & 968 & 1.00 & & \\
\hline One mutation in one exon & 264 & 1.19 & 0.98 to 1.46 & .082 & 107 & 1.18 & 0.82 to 1.69 & NS & 731 & 0.98 & 0.86 to 1.12 & NS \\
\hline Two mutations in one exon & 7 & 0.96 & 0.39 to 2.32 & NS & 7 & 3.56 & 1.63 to 7.78 & .001 & 14 & 1.10 & 0.55 to 2.22 & NS \\
\hline Two mutations in two exons & 19 & 1.29 & 0.74 to 2.26 & NS & 4 & 1.52 & 0.37 to 6.19 & NS & 27 & 0.75 & 0.44 to 1.28 & NS \\
\hline \multicolumn{13}{|l|}{ Amino acid change } \\
\hline WT & 563 & 1.00 & & & 164 & 1.00 & & & 968 & 1.00 & & \\
\hline Same side group & 70 & 0.99 & 0.69 to 1.41 & NS & 28 & 1.77 & 1.04 to 3.01 & .035 & 243 & 0.92 & 0.75 to 1.12 & NS \\
\hline Different side group & 95 & 1.20 & 0.89 to 1.62 & NS & 36 & 0.77 & 0.42 to 1.42 & NS & 248 & 0.87 & 0.71 to 1.06 & NS \\
\hline Amino acid loss & 43 & 1.12 & 0.74 to 1.71 & NS & 14 & 2.35 & 1.21 to 4.59 & 0.012 & 111 & 1.30 & 1.01 to 1.67 & 0.045 \\
\hline \multicolumn{13}{|l|}{ Amino acid type } \\
\hline WT & 563 & 1.00 & & & 164 & 1.00 & & & 968 & 1.00 & & \\
\hline Polar neutral & 55 & 1.25 & 0.87 to 1.79 & NS & 22 & 2.03 & 1.14 to 3.61 & .016 & 180 & 1.00 & 0.81 to 1.24 & NS \\
\hline Other type (apolar neutral, basic, acid) & 151 & 1.04 & 0.81 to 1.34 & NS & 55 & 1.11 & 4.89 to 1.76 & NS & 422 & 0.93 & 0.79 to 1.09 & NS \\
\hline
\end{tabular}

mutated TP53, better survival with chemotherapy was only observed for the proximal colon tumor group $(P<.001)$. TP53 mutation had no predictive value within Dukes' $C$ patient groups treated by surgery alone or within those treated by surgery and chemotherapy (results not shown).

\section{DISCUSSION}

Although a large number of research groups have studied TP53 gene mutations in CRC, controversy still exists regarding the prognostic significance of this alteration. ${ }^{36}$ The likely explanation for this is the insufficient statistical power of the various individual studies. Another reason might be that most studies have considered the prognostic significance of all mutations combined. These are usually within the conserved region spanning exons 5 to 8 (codons 130 to 286). However, several authors have suggested that mutations that affect certain functionally important regions of the TP53 protein may have a stronger prognostic impact. ${ }^{7,9}$ Another reason for discordance in the literature may be that CRC has often been considered a single disease. There is increasing evidence to suggest that different pathways of tumor progression exist within different anatomic regions of the colon, 2,37,38 and hence, TP53 mutations may have a different prognostic impact depending on the site of tumor origin. Finally, the prognostic significance of TP53 mutation may also depend on the adjuvant treatment status of the patient group being studied.

The TP53-CRC International Collaborative Study is the largest study to date on the prognostic value of TP53 


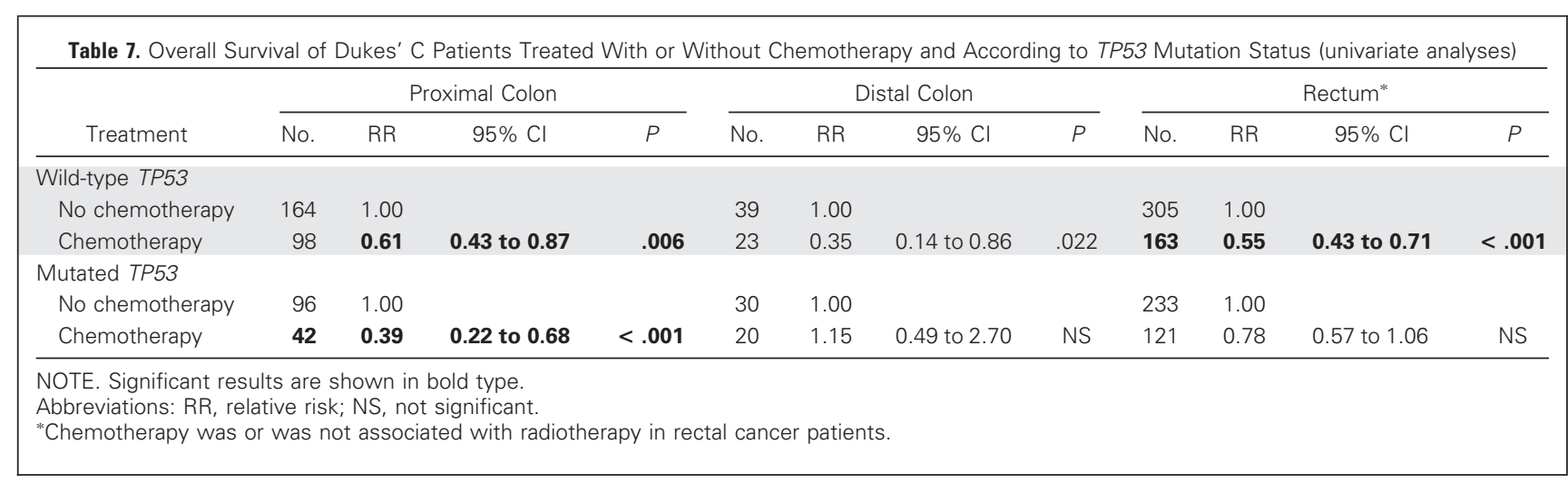

mutations in colorectal cancer. The large sample size has allowed investigation of factors that might influence the prognostic significance of this genetic alteration, including tumor site, type of mutation, and adjuvant therapy status. In accordance with other reports, ${ }^{12,37}$ distal colon and rectal tumors were found to have significantly more mutations than proximal colon tumors $(45 \%, 45 \%$, and $34 \%$, respectively; Table 4 ). Other genetic and epigenetic alterations also differ in frequency according to tumor site and include microsatellite instability, the cytosine phosphate guanine island methylator phenotype, aneuploidy, and loss of heterozygosity. ${ }^{39,40}$ In agreement with the proposal that TP53 mutation occurs late in tumor progression, ${ }^{11}$ the frequency of this alteration increased with advancing tumor stage (Table 4).

Regarding other clinical features of CRC, TP53 mutations were associated with lymphatic invasion in proximal colon and showed trends toward statistical significance for associations with lymphatic (rectal tumors) and vascular invasion (distal and rectal tumors). We found no associations between specific TP53 mutations and clinicopathologic variables other than that frameshift mutations were strongly associated with lymphatic invasion in the proximal colon. These data suggest that TP53 frameshift mutations might be a useful marker of more advanced and aggressive cancer arising at this site.

Our study also demonstrated some interesting trends $(P<.05)$ for associations in rectal cancer among any TP53 mutation or frameshift TP53 mutation and advanced Dukes' stage, lymphatic invasion, and vascular invasion. This might be explained by different biologic effects of mutagenic agents (eg, alkylating agents) depending on site in the large bowel. There have been reports that certain dietary-associated risks are strongest in the distal colon. ${ }^{41}$ In the rectum, the presence of these mutagenic agents for a longer period might have more pronounced effects on TP53 mutation and cause the observed associations with more aggressive clinicopathologic features. At present there are no other reports enabling confirmation of our hypothesis; no studies have been conducted on the effect of these mutagenic agents on rectal cancer and on specific TP53 mutations at this site.

As expected, the conventional clinicopathologic variables (Dukes' stage, histological grade, mucinous status, node status, lymphatic invasion, tumor type, and surgical resection) each showed prognostic value in this cohort of CRC patients (Table 3). Small deletions of the TP53 gene causing amino acid loss were also found to be an independent prognostic factor in distal colon tumors in our study (Table 6). The prognostic significance of this type of TP53 mutation has not been reported previously for any tumor type. It is generally recognized that chromosomal region $17 \mathrm{p} 13.1$ containing the TP53 gene is subjected frequently to allelic deletions in human CRC. ${ }^{42-45}$

Kern et $\mathrm{al}^{43}$ have found that analysis of allelic deletions may be an efficient means to identify subsets of CRC patients at higher risk for distant metastases and cancerrelated death, especially with regard to left-sided tumors. Not all studies have been able to confirm the prognostic significance of $17 \mathrm{p}$ allelic loss, however. ${ }^{45}$ The current findings suggest that small deletions in the TP53 gene in distal colon tumors leading to loss of amino acids might provide more valuable prognostic information than allelic loss. In addition, TP53 mutations in exon 5 showed a trend toward statistical significance when OS was considered in patients with proximal colon tumors (Table 6). Other authors have reported previously that mutations in specific TP53 exons are factors for poor prognosis in colorectal and lung cancers ${ }^{6,46}$ and Vega et $\mathrm{al}^{47}$ have reported that mutations in exon 5 are associated with shortened survival in non-smallcell lung cancer.

None of the different TP53 mutation types evaluated in this study showed independent prognostic value in rectal tumors. The different behavior of rectal tumors compared with tumors from other anatomic regions of the colon may have been masked in previous studies by the grouping of all colorectal tumors together. Furthermore, in rectal cancers the quality of surgery is an important factor in outcome, 
particularly whether total mesorectal excision is carried out, and hence it will not be possible to clarify the role of individual prognostic factors at this site until standardized surgery is performed. ${ }^{48}$ Until recently, there have been few studies dealing with biologic differences between tumors of the colon and those of the rectum, ${ }^{48}$ and few authors have investigated the prognostic role of TP53 in rectal carcinoma. The present results agree with some previous reports ${ }^{49,50}$ but do not support those of a recent study by Rebischung et al, ${ }^{51}$ in which they state that TP53 status is an independent prognostic factor of survival in rectal carcinoma.

One of the most important clinical applications of this study involves the possibility for improved selection of patients to receive chemotherapy. Molecular profiling may serve as a complement to established morphologic parameters for the improved identification of chemotherapyresponsive patients. The response to most drugs, including $\mathrm{FU}$, is complex and therefore unlikely to be explained by any single genetic alteration. However, in vitro studies have shown that disruption of TP53 causes colorectal cancer cells to be more resistant to the apoptotic effects of FU. ${ }^{52}$ In agreement with these observations, we found that colorectal cancer patients with wild-type TP53 have significantly better survival when treated with chemotherapy compared with those treated with surgery alone, regardless of tumor site (Table 7). In contrast, for patients with mutated TP53, only those with proximal colon cancers showed significantly better survival when treated with chemotherapy compared with those treated by surgery alone. These results should be interpreted with caution because of the nonrandomized nature of the chemotherapy treatment. In addition, we grouped all FU-based treatment regimens into one group, even though TP53 mutation may show different predictive values according to the exact type of treatment used. Nevertheless, our results suggest that use of chemotherapy can influence survival depending on TP53 mutation status; this may also be dependent on tumor site. Previous studies showing site-related differences in the frequency of TP53 mutations and other genetic or epigenetic alterations have also suggested that these findings could translate into differential survival benefits from chemotherapy. ${ }^{37,53}$

This study also investigated the effect of TP53 mutations in patients with Dukes' stage $\mathrm{C}$ rectal cancer who underwent adjuvant chemotherapy with or without radiotherapy. In vitro studies have demonstrated that cells with TP53 mutations show reduced radiation-induced growth arrest and increased radioresistance, ${ }^{54,55}$ although ionizing radiation may induce apoptosis through TP53-independent mechanisms. ${ }^{56}$ Our results and other studies ${ }^{57,58}$ show that rectal tumor patients with wild-type TP53 derived significant survival benefit from the use of FU-based chemotherapy, whether combined with radiotherapy or not. Because the current study was retrospective, not all groups that contributed data were able to provide information about treatment modality. Moreover, in the period before 1991, few patients received adjuvant treat- ment. These results should therefore be considered as preliminary only.

In conclusion, the results of the TP53-CRC International Collaborative Study demonstrate the importance of primary tumor site when analyzing the prognostic value of TP53 mutations in CRC. In addition, different types of TP53 mutation might play a pivotal role in determining the biologic behavior of CRC from different sites and hence the prognosis of patients. This meta-analysis found evidence for interesting tumor site differences in the predictive value of TP53 mutation for survival benefit from FU chemotherapy. We believe that additional trials on the prognostic value of TP53 mutation are probably not warranted in view of the relatively weak associations observed here (Table 6) and the emergence of newer technologies that investigate genome-wide markers. ${ }^{59}$ Additional trials to evaluate the predictive significance of TP53 mutation are justified, however, in light of the present findings (Table 7). These would require sufficient patient numbers to allow multivariate analysis, and preferably would involve homogenous treatment regimens and standardized TP53 mutation screening techniques.

\section{Acknowledgment}

We thank Pamela Gardner for help in the preparation of the text.

\section{Appendix}

The following institutions participated in the study and are members of the TP53-CRC collaborative group. Australia: Hany Elsaleh, Richie Soong, University of Western Australia, Nedlands. Austria: Daniela Kandioler, Elisabeth Janschek, and Sonja Kappel, University of Vienna, Medical School, Vienna. China: Maria Lung, Cheung-Shing S. Leung, and Josephine M Ko, Department of Biology, Hong Kong University of Science \& Technology, Clear Water Bay, Kowloon, Hong Kong (SAR), People's Republic of China; Sui T. Yuen and Judy W.C. Ho, Department of Pathology, Queen Mary Hospital, Pokfulam, Hong Kong. France: Evelyne Crapez, Jacqueline Duffour, and Marc Ychou, CRLC Val d'Aurelle, Research Cancer Center, Parc Euromédecine, Montpellier, Cedex. Ireland: Dermot T. Leahy, Department of Pathology, Conway Institute of Biomolecular and Biomedical Research, University College Dublin, Dublin; Diarmuid P. O'Donoghue, Centre for Colorectal Disease, St Vincent's University Hospital, Dublin. Italy: Valentina Agnese and Pasqua Sandra Sisto, Department of Oncology, Università di Palermo; G. Dardanoni, Epidemiological Observatory Center of Sicilian, Palermo; Luigi Chieco-Bianchi and Roberta Bertorelle, Immunology and Molecular Oncology Unit, Padova City Hospital and Department of Oncology and Surgical Sciences, Oncology Section, University of Padova; Claudio Belluco, Department of Oncology and Surgical Sciences, Surgery Section, University of Padova; Walter Giaretti and Silvia Molinu, 
National Institut for Cancer Research, Department Oncogenesis, Lab Biophysics and Cytometry, Genoa; Enrico Ricevuto and Corrado Ficorella, Medical Oncology Unit, Department Experimental Medicine, University of L'Aquila, L'Aquila; Silvano Bosari and Carmelo D. Arizzi, Department of Medicine, Surgery and Dentistry, Division of Pathology, University of Milan, AO San Paolo e IRCCS Ospedale Maggiore, Milan. Japan: Michiko Miyaki, Hereditary Tumor Research Project, Tokyo Metropolitan Komagome Hospital, Bunkyo-ku, Tokyo; Masamitsu Onda, Nippon Medical School, Institute of Gerontology, Department of Molecular Biology, Nakahara-ku, Kawasaki. Netherlands: Ellen Kampman and Brenda Diergaarde, Division of $\mathrm{Hu}-$ man Nutrition, Wageningen University, Wageningen. Norway: Ragnhild A. Lothe and Chieu B. Diep, Department of Genetics, Institute for Cancer Research, the Norwegian Radium Hospital, and Department of Molecular Biosciences, University of Oslo; Gunn I Meling, Institute of Forensic Medicine, University of Oslo, Rikshospitalet, University Hospital and Department of Surgery, Akershus University Hospital, University of Oslo; Poland: Jerzy Ostrowski and Lech Trzeciak, Department of Gastroenterology, Medical Center for Postgraduate Education, Maria Sklodowska-Curie Memorial Cancer Center, Warsaw; Katarzyna Guzińska-Ustymowicz and Bogdan Zalewski, Department of General Pathomorphology, Medical University of Białystok. Spain: Gabriel M. Capellá and Victor Moreno, Department of Epidemiology and Cancer Registry, Institut Català d'Oncologia, L'Hospitalet de Llobregat, Barcelona; Miguel A Peinado, Department of Molecular Oncology, Institut de Recerca, Oncològica, L'Hospitalet de Llobregat, Barcelona. Sweden: Christina Lönnroth and Kent Lundholm, Göteborg University, Institute of Surgical Sciences, Department of Surgery, Sahlgrenska University Hospital, Göteborg; Xiao-Feng Sun and Agnata Jansson, Department of Oncology, Institute of Biomedicine and Surgery, Linköping University Linköping. Switzerland: Hanifa Bouzourene, Institute of Pathology, Centre Hospitalier Universitaire Vaudois, Lausanne. Taiwan: Ling-Ling Hsieh, Department of Public Health, Chang Gung University, Tao-Yuan; Reiping Tang, Colorectal Section, Chang Gung Memorial Hospital, Tao-Yuan. Thailand: Duncan R. Smith, Institute of Molecular Biology and Genetics, Mahidol University, Salaya Campus, Nakorn Pathos. United Kingdom: Timothy G. Allen-Mersh and Zulfiqar A.J. Khan, Department of Surgery, Faculty of Medicine, Imperial College of Science Technology and Medicine, Chelsea \& Westminster Hospital, London; Janice Royds, Department of Pathology, Dunedin School of Medicine, University of Otago, Dunedin, New Zealand; Andrew J. Shorthouse, Royal Hallamshire Hospital, Sheffield. United States: Mark L. Silverman, Department of Pathology, Lahey Clinic Medical Center, Burlington, MA.

\section{Authors' Disclosures of Potential Conflicts of Interest}

The authors indicated no potential conflicts of interest. 


\begin{tabular}{|c|c|c|c|}
\hline \multicolumn{4}{|c|}{$\begin{array}{c}\text { Appendix: Supplementary Table. Patient and Tumor Characteristics From Individual Study Centers That Contributed Data to the } \\
\text { TP53-CRC Meta-Analysis }\end{array}$} \\
\hline Characteristic & No. Proximal Colon & No. Distal Colon & No. Rectum \\
\hline \multicolumn{4}{|l|}{ lacopetta et al $^{14}$ : Australia } \\
\hline Total & 342 & 99 & 680 \\
\hline \multicolumn{4}{|l|}{ Age, years } \\
\hline$<50$ & 22 & 9 & 78 \\
\hline $50-75$ & 215 & 65 & 424 \\
\hline$>75$ & 105 & 25 & 178 \\
\hline \multicolumn{4}{|l|}{ Sex } \\
\hline Male & 150 & 48 & 353 \\
\hline Female & 192 & 51 & 327 \\
\hline \multicolumn{4}{|l|}{ Dukes' stage } \\
\hline A & 5 & 2 & 11 \\
\hline B & 83 & 21 & 167 \\
\hline $\mathrm{C}$ & 247 & 75 & 493 \\
\hline $\mathrm{D}$ & 7 & 1 & 9 \\
\hline \multicolumn{4}{|l|}{ Histologic grade } \\
\hline G1 & 32 & 17 & 82 \\
\hline $\mathrm{G} 2$ & 211 & 63 & 445 \\
\hline G3 & 95 & 17 & 115 \\
\hline \multicolumn{4}{|c|}{ Chemotherapy treatment (Dukes' $\mathrm{C}$ stage)* } \\
\hline Yes & 77 & 27 & 149 \\
\hline No & 170 & 48 & 344 \\
\hline \multicolumn{4}{|l|}{ Kandioler et al ${ }^{15}$ : Austria } \\
\hline Total & 10 & 1 & 62 \\
\hline \multicolumn{4}{|l|}{ Age, years } \\
\hline$<50$ & 0 & 0 & 12 \\
\hline $50-75$ & 9 & 1 & 45 \\
\hline$>75$ & 1 & 0 & 4 \\
\hline \multicolumn{4}{|l|}{ Sex } \\
\hline Male & 6 & 1 & 39 \\
\hline Female & 4 & 0 & 23 \\
\hline \multicolumn{4}{|l|}{ Dukes' stage } \\
\hline$A$ & 0 & 0 & 13 \\
\hline B & 0 & 0 & 18 \\
\hline C & 10 & 1 & 26 \\
\hline D & 0 & 0 & 4 \\
\hline \multicolumn{4}{|l|}{ Histologic grade } \\
\hline $\mathrm{G} 1$ & 32 & 0 & 1 \\
\hline $\mathrm{G} 2$ & 211 & 0 & 33 \\
\hline G3 & 95 & 0 & 17 \\
\hline \multicolumn{4}{|c|}{ Chemotherapy treatment (Dukes' C stage)* } \\
\hline Yes & 9 & 1 & 16 \\
\hline No & 1 & 0 & 10 \\
\hline \multicolumn{4}{|l|}{ Lung et $\mathrm{al}^{16}$ : China } \\
\hline Total & 23 & 10 & 64 \\
\hline \multicolumn{4}{|l|}{ Age, years } \\
\hline$<50$ & 4 & 0 & 15 \\
\hline $50-75$ & 15 & 6 & 34 \\
\hline$>75$ & 4 & 4 & 15 \\
\hline \multicolumn{4}{|l|}{ Sex } \\
\hline Male & 15 & 4 & 38 \\
\hline Female & 8 & 6 & 26 \\
\hline \multicolumn{4}{|l|}{ Dukes' stage } \\
\hline A & 1 & 0 & 3 \\
\hline B & 14 & 8 & 33 \\
\hline C & 5 & 1 & 17 \\
\hline D & 3 & 1 & 11 \\
\hline \multicolumn{4}{|c|}{ (continued on following page) } \\
\hline
\end{tabular}




\begin{tabular}{|c|c|c|c|}
\hline \multicolumn{4}{|c|}{$\begin{array}{l}\text { Appendix: Supplementary Table. Patient and Tumor Characteristics From Individual Study Centers That Contributed Data to the } \\
\text { TP53-CRC Meta-Analysis (continued) }\end{array}$} \\
\hline Characteristic & No. Proximal Colon & No. Distal Colon & No. Rectum \\
\hline \multicolumn{4}{|l|}{ Histologic grade } \\
\hline G1 & 2 & 2 & 9 \\
\hline G2 & 15 & 6 & 50 \\
\hline G3 & 5 & 1 & 1 \\
\hline \multicolumn{4}{|c|}{ Chemotherapy treatment (Dukes' $\mathrm{C}$ stage)* } \\
\hline Yes & 0 & 0 & 1 \\
\hline No & 5 & 1 & 16 \\
\hline \multicolumn{4}{|l|}{ Yuen et al ${ }^{17}$ : China } \\
\hline Total & 6 & 4 & 57 \\
\hline \multicolumn{4}{|l|}{ Age, years } \\
\hline$<50$ & 2 & 1 & 17 \\
\hline $50-75$ & 3 & 1 & 21 \\
\hline$>75$ & 1 & 2 & 19 \\
\hline \multicolumn{4}{|l|}{ Sex } \\
\hline Male & 4 & 3 & 32 \\
\hline Female & 2 & 1 & 25 \\
\hline \multicolumn{4}{|l|}{ Dukes' stage } \\
\hline A & 0 & 1 & 13 \\
\hline B & 2 & 1 & 19 \\
\hline C & 2 & 2 & 21 \\
\hline D & 2 & 0 & 4 \\
\hline \multicolumn{4}{|l|}{ Histologic grade } \\
\hline G1 & 1 & 1 & 10 \\
\hline G2 & 4 & 2 & 44 \\
\hline G3 & 0 & 1 & 3 \\
\hline \multicolumn{4}{|c|}{ Chemotherapy treatment (Dukes' C stage)* } \\
\hline Yes & 0 & 0 & 3 \\
\hline No & 2 & 2 & 18 \\
\hline \multicolumn{4}{|l|}{ Crapez et al: France } \\
\hline Total & 30 & 10 & 51 \\
\hline \multicolumn{4}{|l|}{ Age, years } \\
\hline$<50$ & 2 & 4 & 4 \\
\hline $50-75$ & 12 & 4 & 31 \\
\hline$>75$ & 16 & 2 & 16 \\
\hline \multicolumn{4}{|l|}{ Sex } \\
\hline Male & 11 & 6 & 23 \\
\hline Female & 19 & 4 & 28 \\
\hline \multicolumn{4}{|l|}{ Dukes' stage } \\
\hline A & 2 & 2 & 13 \\
\hline B & 9 & 5 & 16 \\
\hline C & 8 & 0 & 10 \\
\hline D & 11 & 3 & 12 \\
\hline \multicolumn{4}{|l|}{ Histologic grade } \\
\hline G1 & 11 & 5 & 32 \\
\hline G2 & 13 & 4 & 17 \\
\hline G3 & 5 & 1 & 1 \\
\hline \multicolumn{4}{|c|}{ Chemotherapy treatment (Dukes' C stage)* } \\
\hline Yes & 5 & 0 & 5 \\
\hline No & 3 & 0 & 5 \\
\hline Leahy et al ${ }^{18}$ : Ireland & & & \\
\hline Total & 17 & 2 & 47 \\
\hline Age, years & & & \\
\hline$<50$ & 3 & 0 & 2 \\
\hline $50-75$ & 3 & 1 & 37 \\
\hline$>75$ & 11 & 1 & 8 \\
\hline Sex & & & \\
\hline Male & 0 & 1 & 32 \\
\hline Female & 6 & 1 & 15 \\
\hline Dukes' stage & & & \\
\hline A & 2 & 0 & 12 \\
\hline B & 6 & 1 & 16 \\
\hline & ntinued on following & & \\
\hline
\end{tabular}




\begin{tabular}{|c|c|c|c|}
\hline \multicolumn{4}{|c|}{$\begin{array}{c}\text { Appendix: Supplementary Table. Patient and Tumor Characteristics From Individual Study Centers That Contributed Data to the } \\
\text { TP53-CRC Meta-Analysis (continued) }\end{array}$} \\
\hline Characteristic & No. Proximal Colon & No. Distal Colon & No. Rectum \\
\hline C & 9 & 1 & 19 \\
\hline D & 0 & 0 & 0 \\
\hline \multicolumn{4}{|l|}{ Histologic grade } \\
\hline G1 & 0 & 0 & 0 \\
\hline $\mathrm{G} 2$ & 12 & 2 & 42 \\
\hline G3 & 5 & 0 & 5 \\
\hline \multicolumn{4}{|c|}{ Chemotherapy treatment (Dukes' $\mathrm{C}$ stage) ${ }^{*}$} \\
\hline Yes & 0 & 0 & 0 \\
\hline No & 9 & 1 & 19 \\
\hline \multicolumn{4}{|l|}{ Chieco-Bianchi et al ${ }^{19}$ : Italy } \\
\hline Total & 87 & 119 & 123 \\
\hline \multicolumn{4}{|l|}{ Age, years } \\
\hline$<50$ & 7 & 13 & 19 \\
\hline $50-75$ & 55 & 94 & 87 \\
\hline$>75$ & 24 & 12 & 17 \\
\hline \multicolumn{4}{|l|}{ Sex } \\
\hline Male & 48 & 75 & 81 \\
\hline Female & 39 & 44 & 42 \\
\hline \multicolumn{4}{|l|}{ Dukes' stage } \\
\hline A & 12 & 13 & 33 \\
\hline$B$ & 32 & 40 & 37 \\
\hline C & 23 & 37 & 24 \\
\hline $\mathrm{D}$ & 20 & 29 & 29 \\
\hline \multicolumn{4}{|l|}{ Histologic grade } \\
\hline G1 & 14 & 28 & 25 \\
\hline G2 & 50 & 86 & 80 \\
\hline G3 & 18 & 3 & 14 \\
\hline \multicolumn{4}{|c|}{ Chemotherapy treatment (Dukes' C stage)* } \\
\hline Yes & 0 & 0 & 0 \\
\hline No & 0 & 0 & 0 \\
\hline \multicolumn{4}{|l|}{ Giaretti et $\mathrm{al}^{20}$ : Italy } \\
\hline Total & 19 & 7 & 30 \\
\hline \multicolumn{4}{|l|}{ Age, years } \\
\hline$<50$ & 2 & 0 & 3 \\
\hline $50-75$ & 10 & 2 & 20 \\
\hline$>75$ & 2 & 2 & 2 \\
\hline \multicolumn{4}{|l|}{ Sex } \\
\hline Male & 8 & 3 & 16 \\
\hline Female & 9 & 3 & 13 \\
\hline \multicolumn{4}{|l|}{ Dukes' stage } \\
\hline$A$ & 2 & 0 & 10 \\
\hline B & 11 & 3 & 7 \\
\hline C & 6 & 4 & 12 \\
\hline D & 0 & 0 & 0 \\
\hline \multicolumn{4}{|l|}{ Histologic grade } \\
\hline $\mathrm{G} 1$ & 1 & 2 & 5 \\
\hline $\mathrm{G} 2$ & 15 & 4 & 17 \\
\hline G3 & 1 & 1 & 4 \\
\hline \multicolumn{4}{|c|}{ Chemotherapy treatment (Dukes' C stage)* } \\
\hline Yes & 0 & 0 & 0 \\
\hline No & 0 & 0 & 0 \\
\hline \multicolumn{4}{|l|}{ Ricevuto et al: Italy } \\
\hline Total & 15 & 6 & 22 \\
\hline Age, years & & & \\
\hline$<50$ & 1 & 0 & 3 \\
\hline $50-75$ & 13 & 6 & 19 \\
\hline$>75$ & 1 & 0 & 0 \\
\hline Sex & & & \\
\hline Male & 8 & 4 & 14 \\
\hline Female & 7 & 2 & 8 \\
\hline & ntinued on following $\mathrm{p}$ & & \\
\hline
\end{tabular}




\begin{tabular}{|c|c|c|c|}
\hline \multicolumn{4}{|c|}{$\begin{array}{c}\text { Appendix: Supplementary Table. Patient and Tumor Characteristics From Individual Study Centers That Contributed Data to the } \\
\text { TP53-CRC Meta-Analysis (continued) }\end{array}$} \\
\hline Characteristic & No. Proximal Colon & No. Distal Colon & No. Rectum \\
\hline \multicolumn{4}{|l|}{ Dukes' stage } \\
\hline A & 3 & 0 & 5 \\
\hline$B$ & 5 & 4 & 9 \\
\hline $\mathrm{C}$ & 5 & 2 & 6 \\
\hline $\mathrm{D}$ & 2 & 0 & 1 \\
\hline \multicolumn{4}{|l|}{ Histologic grade } \\
\hline G1 & 1 & 1 & 2 \\
\hline G2 & 12 & 4 & 17 \\
\hline G3 & 2 & 0 & 1 \\
\hline \multicolumn{4}{|c|}{ Chemotherapy treatment (Dukes' C stage)* } \\
\hline Yes & 3 & 2 & 5 \\
\hline No & 2 & 0 & 1 \\
\hline \multicolumn{4}{|l|}{ Russo et al $\left.\right|^{9}$ : Italy } \\
\hline Total & 31 & 52 & 77 \\
\hline \multicolumn{4}{|l|}{ Age, years } \\
\hline$<50$ & 2 & 3 & 9 \\
\hline $50-75$ & 20 & 39 & 52 \\
\hline$>75$ & 9 & 10 & 16 \\
\hline \multicolumn{4}{|l|}{ Sex } \\
\hline Male & 12 & 20 & 44 \\
\hline Female & 19 & 32 & 33 \\
\hline \multicolumn{4}{|l|}{ Dukes' stage } \\
\hline A & 6 & 11 & 23 \\
\hline B & 11 & 15 & 25 \\
\hline C & 10 & 13 & 18 \\
\hline D & 4 & 13 & 11 \\
\hline \multicolumn{4}{|l|}{ Histologic grade } \\
\hline $\mathrm{G} 1$ & 21 & 10 & 10 \\
\hline G2 & 7 & 37 & 46 \\
\hline G3 & 0 & 5 & 21 \\
\hline \multicolumn{4}{|c|}{ Chemotherapy treatment (Dukes' $\mathrm{C}$ stage) ${ }^{*}$} \\
\hline Yes & 5 & 4 & 4 \\
\hline No & 5 & 9 & 14 \\
\hline \multicolumn{4}{|l|}{ Miyachi et $\mathrm{al}^{21}$ : Japan } \\
\hline Total & 14 & 4 & 39 \\
\hline \multicolumn{4}{|l|}{ Age, years } \\
\hline$<50$ & 2 & 0 & 3 \\
\hline $50-75$ & 9 & 3 & 30 \\
\hline$>75$ & 3 & 1 & 6 \\
\hline \multicolumn{4}{|l|}{ Sex } \\
\hline Male & 10 & 1 & 22 \\
\hline Female & 4 & 3 & 17 \\
\hline \multicolumn{4}{|l|}{ Dukes' stage } \\
\hline$A$ & 4 & 0 & 12 \\
\hline B & 7 & 1 & 11 \\
\hline C & 3 & 3 & 16 \\
\hline $\mathrm{D}$ & 0 & 0 & 0 \\
\hline \multicolumn{4}{|l|}{ Histologic grade } \\
\hline G1 & 9 & 2 & 27 \\
\hline $\mathrm{G} 2$ & 2 & 2 & 10 \\
\hline G3 & 1 & 0 & 0 \\
\hline \multicolumn{4}{|c|}{ Chemotherapy treatment (Dukes' $\mathrm{C}$ stage)* } \\
\hline Yes & 0 & 0 & 0 \\
\hline No & 0 & 0 & 0 \\
\hline Onda et $\mathrm{al}^{22}$ : Japan & & & \\
\hline Total & 14 & 0 & 31 \\
\hline Age, years & & & \\
\hline$<50$ & 0 & 0 & 6 \\
\hline $50-75$ & 9 & 0 & 23 \\
\hline$>75$ & 5 & 0 & 2 \\
\hline & ntinued on following $\mathrm{p}$ & & \\
\hline
\end{tabular}




\begin{tabular}{|c|c|c|c|}
\hline \multicolumn{4}{|c|}{$\begin{array}{c}\text { Appendix: Supplementary Table. Patient and Tumor Characteristics From Individual Study Centers That Contributed Data to the } \\
\text { TP53-CRC Meta-Analysis (continued) }\end{array}$} \\
\hline Characteristic & No. Proximal Colon & No. Distal Colon & No. Rectum \\
\hline \multicolumn{4}{|l|}{ Sex } \\
\hline Male & 6 & 0 & 18 \\
\hline Female & 8 & 0 & 13 \\
\hline \multicolumn{4}{|l|}{ Dukes' stage } \\
\hline A & 5 & 0 & 6 \\
\hline B & 4 & 0 & 10 \\
\hline C & 5 & 0 & 13 \\
\hline D & 0 & 0 & 1 \\
\hline \multicolumn{4}{|l|}{ Histologic grade } \\
\hline G1 & 7 & 0 & 10 \\
\hline $\mathrm{G} 2$ & 7 & 0 & 18 \\
\hline G3 & 0 & 0 & 1 \\
\hline \multicolumn{4}{|c|}{ Chemotherapy treatment (Dukes' C stage) $)^{*}$} \\
\hline Yes & 5 & 0 & 11 \\
\hline No & 0 & 0 & 2 \\
\hline \multicolumn{4}{|l|}{ Kampman et $\mathrm{al}^{23}$ : Netherlands } \\
\hline Total & 77 & 21 & 74 \\
\hline \multicolumn{4}{|l|}{ Age, years } \\
\hline$<50$ & 13 & 1 & 12 \\
\hline $50-75$ & 59 & 20 & 58 \\
\hline$>75$ & 5 & 0 & 4 \\
\hline \multicolumn{4}{|l|}{ Sex } \\
\hline Male & 40 & 14 & 46 \\
\hline Female & 37 & 7 & 28 \\
\hline \multicolumn{4}{|l|}{ Dukes' stage } \\
\hline A & 4 & 4 & 17 \\
\hline B & 41 & 13 & 28 \\
\hline C & 21 & 4 & 22 \\
\hline $\mathrm{D}$ & 10 & 0 & 7 \\
\hline \multicolumn{4}{|l|}{ Histologic grade } \\
\hline G1 & 14 & 2 & 11 \\
\hline $\mathrm{G} 2$ & 33 & 12 & 49 \\
\hline G3 & 29 & 5 & 12 \\
\hline \multicolumn{4}{|c|}{ Chemotherapy treatment (Dukes' C stage) ${ }^{*}$} \\
\hline Yes & 5 & 1 & 5 \\
\hline No & 16 & 3 & 16 \\
\hline \multicolumn{4}{|l|}{ Lothe et $\mathrm{al}^{24}$ : Norway } \\
\hline Total & 67 & 11 & 143 \\
\hline \multicolumn{4}{|l|}{ Age, years } \\
\hline$<50$ & 3 & 2 & 14 \\
\hline $50-75$ & 41 & 7 & 88 \\
\hline$>75$ & 23 & 2 & 41 \\
\hline \multicolumn{4}{|l|}{ Sex } \\
\hline Male & 36 & 5 & 64 \\
\hline Female & 31 & 6 & 79 \\
\hline Dukes' stage & & & \\
\hline A & 6 & 1 & 25 \\
\hline B & 29 & 7 & 63 \\
\hline C & 23 & 2 & 42 \\
\hline $\mathrm{D}$ & 9 & 1 & 13 \\
\hline Histologic grade & & & \\
\hline $\mathrm{G} 1$ & 18 & 2 & 11 \\
\hline $\mathrm{G} 2$ & 45 & 9 & 122 \\
\hline G3 & 4 & 0 & 10 \\
\hline Chemotherapy treatment ( $\mathrm{D}$ & & & \\
\hline Yes & 0 & 0 & 0 \\
\hline No & 0 & 0 & 0 \\
\hline Guzinska et al: Poland & & & \\
\hline Total & 6 & 1 & 40 \\
\hline Age, years & & & \\
\hline$<50$ & 1 & 0 & 6 \\
\hline $50-75$ & 5 & 1 & 27 \\
\hline$>75$ & 0 & 0 & 7 \\
\hline & ntinued on following & & \\
\hline
\end{tabular}




\begin{tabular}{|c|c|c|c|}
\hline \multicolumn{4}{|c|}{$\begin{array}{c}\text { Appendix: Supplementary Table. Patient and Tumor Characteristics From Individual Study Centers That Contributed Data to the } \\
\text { TP53-CRC Meta-Analysis (continued) }\end{array}$} \\
\hline Characteristic & No. Proximal Colon & No. Distal Colon & No. Rectum \\
\hline \multicolumn{4}{|l|}{ Sex } \\
\hline Male & 4 & 1 & 23 \\
\hline Female & 2 & 0 & 17 \\
\hline \multicolumn{4}{|l|}{ Dukes' stage } \\
\hline A & 0 & 0 & 1 \\
\hline B & 0 & 0 & 4 \\
\hline C & 6 & 0 & 35 \\
\hline $\mathrm{D}$ & 0 & 1 & 0 \\
\hline \multicolumn{4}{|l|}{ Histologic grade } \\
\hline G1 & 0 & 0 & 2 \\
\hline $\mathrm{G} 2$ & 3 & 0 & 29 \\
\hline G3 & 2 & 1 & 4 \\
\hline \multicolumn{4}{|c|}{ Chemotherapy treatment (Dukes' C stage)* } \\
\hline Yes & 3 & 0 & 12 \\
\hline No & 3 & 1 & 23 \\
\hline \multicolumn{4}{|l|}{ Ostrowski et al ${ }^{25}$ : Poland } \\
\hline Total & 11 & 2 & 37 \\
\hline \multicolumn{4}{|l|}{ Age, years } \\
\hline$<50$ & 1 & 0 & 9 \\
\hline $50-75$ & 8 & 1 & 27 \\
\hline$>75$ & 2 & 1 & 1 \\
\hline \multicolumn{4}{|l|}{ Sex } \\
\hline Male & 4 & 0 & 23 \\
\hline Female & 7 & 2 & 14 \\
\hline \multicolumn{4}{|l|}{ Dukes' stage } \\
\hline A & 0 & 0 & 6 \\
\hline B & 4 & 2 & 11 \\
\hline $\mathrm{C}$ & 5 & 0 & 12 \\
\hline $\mathrm{D}$ & 2 & 0 & 6 \\
\hline \multicolumn{4}{|l|}{ Histologic grade } \\
\hline $\mathrm{G} 1$ & 1 & 0 & 4 \\
\hline $\mathrm{G} 2$ & 8 & 2 & 29 \\
\hline G3 & 2 & 0 & 1 \\
\hline \multicolumn{4}{|c|}{ Chemotherapy treatment (Dukes' C stage)* } \\
\hline Yes & 4 & 0 & 9 \\
\hline No & 1 & 0 & 3 \\
\hline \multicolumn{4}{|l|}{ Capellà et $a^{26}$ : Spain } \\
\hline Total & 48 & 16 & 99 \\
\hline \multicolumn{4}{|l|}{ Age, years } \\
\hline$<50$ & 5 & 1 & 7 \\
\hline $50-75$ & 32 & 11 & 65 \\
\hline$>75$ & 11 & 4 & 27 \\
\hline \multicolumn{4}{|l|}{ Sex } \\
\hline Male & 32 & 6 & 63 \\
\hline Female & 16 & 10 & 36 \\
\hline \multicolumn{4}{|l|}{ Dukes' stage } \\
\hline A & 2 & 2 & 21 \\
\hline B & 22 & 8 & 28 \\
\hline C & 16 & 3 & 34 \\
\hline$D$ & 7 & 3 & 14 \\
\hline \multicolumn{4}{|l|}{ Histologic grade } \\
\hline G1 & 0 & 0 & 0 \\
\hline $\mathrm{G} 2$ & 40 & 14 & 91 \\
\hline G3 & 8 & 1 & 7 \\
\hline \multicolumn{4}{|c|}{ Chemotherapy treatment (Dukes' C stage) } \\
\hline Yes & 9 & 2 & 17 \\
\hline No & 7 & 1 & 17 \\
\hline Lonnroth et $\mathrm{al}^{27}$ : Sweden & & & \\
\hline Total & 41 & 1 & 52 \\
\hline
\end{tabular}




\begin{tabular}{|c|c|c|c|}
\hline \multicolumn{4}{|c|}{$\begin{array}{c}\text { Appendix: Supplementary Table. Patient and Tumor Characteristics From Individual Study Centers That Contributed Data to the } \\
\text { TP53-CRC Meta-Analysis (continued) }\end{array}$} \\
\hline Characteristic & No. Proximal Colon & No. Distal Colon & No. Rectum \\
\hline \multicolumn{4}{|l|}{ Age, years } \\
\hline$<50$ & 1 & 0 & 8 \\
\hline $50-75$ & 28 & 1 & 42 \\
\hline$>75$ & 12 & 0 & 2 \\
\hline \multicolumn{4}{|l|}{ Sex } \\
\hline Male & 15 & 0 & 36 \\
\hline Female & 26 & 1 & 16 \\
\hline \multicolumn{4}{|l|}{ Dukes' stage } \\
\hline A & 3 & 0 & 1 \\
\hline B & 16 & 1 & 22 \\
\hline C & 21 & 0 & 25 \\
\hline D & 1 & 0 & 4 \\
\hline \multicolumn{4}{|l|}{ Histologic grade } \\
\hline G1 & 1 & 1 & 2 \\
\hline G2 & 21 & 0 & 45 \\
\hline G3 & 18 & 0 & 4 \\
\hline \multicolumn{4}{|c|}{ Chemotherapy treatment (Dukes' C stage) } \\
\hline Yes & 0 & 0 & 0 \\
\hline No & 21 & 0 & 25 \\
\hline \multicolumn{4}{|l|}{ Sun et $\mathrm{al}^{28}$ : Sweden } \\
\hline Total & 25 & 1 & 47 \\
\hline \multicolumn{4}{|l|}{ Age, years } \\
\hline$<50$ & 0 & 0 & 1 \\
\hline $50-75$ & 15 & 1 & 27 \\
\hline$>75$ & 10 & 0 & 19 \\
\hline \multicolumn{4}{|l|}{ Sex } \\
\hline Male & 9 & 0 & 25 \\
\hline Female & 16 & 1 & 22 \\
\hline \multicolumn{4}{|l|}{ Dukes' stage } \\
\hline A & 2 & 0 & 11 \\
\hline B & 7 & 0 & 9 \\
\hline C & 9 & 1 & 15 \\
\hline D & 7 & 0 & 12 \\
\hline \multicolumn{4}{|l|}{ Histologic grade } \\
\hline G1 & 1 & 0 & 4 \\
\hline G2 & 16 & 1 & 31 \\
\hline G3 & 2 & 0 & 5 \\
\hline \multicolumn{4}{|c|}{ Chemotherapy treatment (Dukes' C stage)* } \\
\hline Yes & 0 & 0 & 0 \\
\hline No & 9 & 1 & 15 \\
\hline \multicolumn{4}{|l|}{ Bouzourene et $\mathrm{al}^{29}$ : Switzerland } \\
\hline Total & 61 & 27 & 35 \\
\hline \multicolumn{4}{|l|}{ Age, years } \\
\hline$<50$ & 2 & 0 & 4 \\
\hline $50-75$ & 35 & 15 & 26 \\
\hline$>75$ & 24 & 12 & 5 \\
\hline \multicolumn{4}{|l|}{ Sex } \\
\hline Male & 33 & 13 & 21 \\
\hline Female & 28 & 14 & 14 \\
\hline Dukes' stage & & & \\
\hline A & 0 & 0 & 0 \\
\hline B & 61 & 27 & 35 \\
\hline C & 0 & 0 & 0 \\
\hline D & 0 & 0 & 0 \\
\hline Histologic grade & & & \\
\hline G1 & 13 & 2 & 3 \\
\hline G2 & 36 & 23 & 29 \\
\hline G3 & 12 & 1 & 3 \\
\hline Chemotherapy treatment (D) & & & \\
\hline Yes & 0 & 0 & 0 \\
\hline No & 0 & 0 & 0 \\
\hline & ntinued on following & & \\
\hline
\end{tabular}




\begin{tabular}{|c|c|c|c|}
\hline \multicolumn{4}{|c|}{$\begin{array}{c}\text { Appendix: Supplementary Table. Patient and Tumor Characteristics From Individual Study Centers That Contributed Data to the } \\
\text { TP53-CRC Meta-Analysis (continued) }\end{array}$} \\
\hline Characteristic & No. Proximal Colon & No. Distal Colon & No. Rectum \\
\hline \multicolumn{4}{|l|}{ Hsieh et $\mathrm{al}^{30}$ : Taiwan } \\
\hline Total & 35 & 18 & 129 \\
\hline \multicolumn{4}{|l|}{ Age, years } \\
\hline$<50$ & 5 & 5 & 30 \\
\hline $50-75$ & 27 & 11 & 87 \\
\hline$>75$ & 3 & 2 & 12 \\
\hline \multicolumn{4}{|l|}{ Sex } \\
\hline Male & 19 & 7 & 79 \\
\hline Female & 16 & 11 & 50 \\
\hline \multicolumn{4}{|l|}{ Dukes' stage } \\
\hline A & 1 & 1 & 15 \\
\hline$B$ & 14 & 9 & 50 \\
\hline C & 19 & 8 & 60 \\
\hline $\mathrm{D}$ & 0 & 0 & 4 \\
\hline \multicolumn{4}{|l|}{ Histologic grade } \\
\hline G1 & 8 & 3 & 27 \\
\hline $\mathrm{G} 2$ & 21 & 11 & 94 \\
\hline G3 & 6 & 4 & 7 \\
\hline \multicolumn{4}{|c|}{ Chemotherapy treatment (Dukes' $\mathrm{C}$ stage) ${ }^{*}$} \\
\hline Yes & 13 & 4 & 44 \\
\hline No & 6 & 4 & 16 \\
\hline \multicolumn{4}{|c|}{ Allan-Mersh et al ${ }^{31}$ : United Kingdom } \\
\hline Total & 2 & 2 & 7 \\
\hline \multicolumn{4}{|l|}{ Age, years } \\
\hline$<50$ & 1 & 0 & 1 \\
\hline $50-75$ & 1 & 2 & 6 \\
\hline$>75$ & 0 & 0 & 0 \\
\hline \multicolumn{4}{|l|}{ Sex } \\
\hline Male & 2 & 0 & 5 \\
\hline Female & 0 & 2 & 2 \\
\hline \multicolumn{4}{|l|}{ Dukes' stage } \\
\hline A & 0 & 0 & 0 \\
\hline B & 0 & 0 & 0 \\
\hline C & 2 & 2 & 5 \\
\hline $\mathrm{D}$ & 0 & 0 & 2 \\
\hline \multicolumn{4}{|l|}{ Histologic grade } \\
\hline G1 & 0 & 0 & 0 \\
\hline $\mathrm{G} 2$ & 0 & 0 & 0 \\
\hline G3 & 0 & 0 & 0 \\
\hline \multicolumn{4}{|c|}{ Chemotherapy treatment (Dukes' $\mathrm{C}$ stage)* } \\
\hline Yes & 2 & 2 & 5 \\
\hline No & 0 & 0 & 0 \\
\hline \multicolumn{4}{|l|}{ Royds et al ${ }^{32}$ : United Kingdom } \\
\hline Total & 4 & 0 & 15 \\
\hline \multicolumn{4}{|l|}{ Age, years } \\
\hline$<50$ & 0 & 0 & 0 \\
\hline $50-75$ & 2 & 0 & 12 \\
\hline$>75$ & 2 & 0 & 3 \\
\hline \multicolumn{4}{|l|}{ Sex } \\
\hline Male & 3 & 0 & 8 \\
\hline Female & 1 & 0 & 7 \\
\hline Dukes' stage & & & \\
\hline A & 0 & 0 & 2 \\
\hline$B$ & 1 & 0 & 7 \\
\hline C & 1 & 0 & 1 \\
\hline $\mathrm{D}$ & 2 & 0 & 5 \\
\hline Histologic grade & & & \\
\hline G1 & 0 & 0 & 1 \\
\hline $\mathrm{G} 2$ & 1 & 0 & 10 \\
\hline G3 & 3 & 0 & 4 \\
\hline & tinued on following & & \\
\hline
\end{tabular}




\begin{tabular}{|c|c|c|c|}
\hline \multicolumn{4}{|c|}{$\begin{array}{c}\text { Appendix: Supplementary Table. Patient and Tumor Characteristics From Individual Study Centers That Contributed Data to the } \\
\text { TP53-CRC Meta-Analysis (continued) }\end{array}$} \\
\hline Characteristic & No. Proximal Colon & No. Distal Colon & No. Rectum \\
\hline \multicolumn{4}{|c|}{ Chemotherapy treatment (Dukes' C stage) } \\
\hline Yes & 0 & 0 & 0 \\
\hline No & 1 & 0 & 1 \\
\hline \multicolumn{4}{|c|}{ Bosari and Silverman ${ }^{33}$ : United States } \\
\hline Total & 32 & 12 & 70 \\
\hline \multicolumn{4}{|l|}{ Age, years } \\
\hline$<50$ & 3 & 2 & 5 \\
\hline $50-75$ & 20 & 6 & 59 \\
\hline$>75$ & 9 & 4 & 6 \\
\hline \multicolumn{4}{|l|}{ Sex } \\
\hline Male & 22 & 6 & 48 \\
\hline Female & 10 & 6 & 22 \\
\hline \multicolumn{4}{|l|}{ Dukes' stage } \\
\hline A & 4 & 1 & 13 \\
\hline B & 12 & 4 & 25 \\
\hline $\mathrm{C}$ & 14 & 4 & 24 \\
\hline $\mathrm{D}$ & 2 & 3 & 7 \\
\hline \multicolumn{4}{|l|}{ Histologic grade } \\
\hline G1 & 2 & 1 & 5 \\
\hline $\mathrm{G} 2$ & 19 & 8 & 50 \\
\hline G3 & 11 & 3 & 15 \\
\hline \multicolumn{4}{|c|}{ Chemotherapy treatment (Dukes' C stage)* } \\
\hline Yes & 0 & 0 & 0 \\
\hline No & 14 & 4 & 24 \\
\hline
\end{tabular}

\section{REFERENCES}

1. Ferlay J, Bray F, Posani P, et al: GLOBOCAN 2000: Cancer Incidence, Mortality and Prevalence Worldwide, Version 1. IARC CancerBase No. 5. Lyon, France, IARC Press, 2001

2. lacopetta B: TP53 mutation in colorectal cancer. Hum Mutat 21:271-276, 2003

3. Beroud C, Soussi T: The UMD-p53 database: New mutations and analysis tools. Hum Mutat 21:176-181, 2003

4. Soussi T, Caron de Fromentel C, May P: Structural aspects of the p53 protein in relation to gene evolution. Oncogene 5:945-952, 1990

5. Borresen-Dale A, Lothe RA, Meling GI, et al: TP53 and long-term prognosis in colorectal cancer: Mutations in the L3 Zinc-binding domain predict poor survival. Clin Cancer Res 4:203-210, 1998

6. Iniesta $\mathrm{P}$, Vega FJ, Caldes $T$, et al: p53 exon 7 mutations as a predictor of poor prognosis in patients with colorectal cancer. Cancer Lett 130:153-160, 1998

7. Samowitz WS, Curtin $K, M a K N$, et al: Prognostic significance of p53 mutations in colon cancer at the population level. Int J Cancer 99:597-602, 2002

8. Jernvall $P$, Makinen $M$, Karttunen $T$, et al: Conserved region mutations of the $\mathrm{p} 53$ gene are concentrated in distal colorectal cancers. Int $J$ Cancer 74:97-101, 1997

9. Russo A, Migliavacca M, Zanna I, et al: p53 mutations in L3-loop zinc-binding domain, DNAploidy, and $\mathrm{S}$ phase fraction are independent prognostic indicators in colorectal cancer: A prospective study with a five-year follow-up. Cancer Epidemiol Biomarkers Prev 11:1322-1331, 2002

10. Baker SJ, Fearon ER, Nigro JM, et al: Chromosome 17 deletions and p53 gene mutations in colorectal carcinomas. Science 244:217221, 1989

11. Fearon ER, Vogelstein B: A genetic model for colorectal tumorigenesis. Cell 61:759-767, 1990

12. Hamelin R, Laurent-Puig $P$, Olschwang $S$, et al: Association of p53 mutations with short survival in colorectal cancer. Gastroenterology 106:42-48, 1994

13. Goh HS, Elnatan J, Low $\mathrm{CH}$, et al: p53 point mutation and survival in colorectal cancer patients: Effect of disease dissemination and tumour location. Int J Oncol 15:491-498, 1999

14. Soong R, Powell B, Elsaleh $H$, et al: Prognostic significance of TP53 gene mutation in 995 cases of colorectal carcinoma: Influence of tumour site, stage, adjuvant chemotherapy and type of mutation. Eur J Cancer 36:2053-2060, 2000
15. Kandioler D, Zwrtek R, Ludwig C, et al: TP53 genotype but not p53 immunohistochemical result predicts response to preoperative short-term radiotherapy in rectal cancer. Ann Surg 235:493-498, 2002

16. Leung CS, Lung ML: Detection of p53 mutations in Hong Kong colorectal carcinomas by conventional PCR-SSCP analysis versus $\mathrm{p} 53$ yeast functional assays. Anticancer Res 19:625 628, 1999

17. Yuen ST, Chung LP, Leung SY, et al: Colorectal carcinoma in Hong Kong: Epidemiology and genetic mutations. Br J Cancer 76:1610 1616, 1997

18. Leahy DT, Salman $R$, Mulcahy $H$, et al: Prognostic significance of p53 abnormalities in colorectal carcinoma detected by PCR-SSCP and immunohistochemical analysis. J Pathol 180 364-370, 1996

19. Bertorelle R, Esposito G, Del Mistro A, et al: Association of p53 gene and protein alterations with metastases in colorectal cancer. Am J Surg Pathol 19:463-471, 1995

20. Giaretti W, Venesio T, Sciutto A, et al: Near-diploid and near-triploid human sporadic colorectal adenocarcinomas differ for KRAS2 and TP53 mutational status. Genes Chromosomes Cancer 37:207-213, 2003 
21. Miyaki $M$, lijima $T$, Yasuno $M$, et al: High incidence of protein-truncating mutations of the p53 gene in liver metastases of colorectal carcinomas. Oncogene 21:6689-6693, 2002

22. Onda M, Abe R, Tsuchiya A, et al: K-ras and p53 gene mutations in colorectal cancer in 57 Japanese patients. Fukushima J Med Sci 43:29-39, 1997

23. Voskuil DW, Kampman $E$, van Kraats $A A$, et al: p53 over-expression and p53 mutations in colon carcinomas: Relation to dietary risk factors. Int J Cancer 81:675-681, 1999

24. Diep CB, Thorstensen L, Meling GI, et al: Genetic tumor markers with prognostic impact in Dukes' stages B and C colorectal cancer patients. J Clin Oncol 21:820-829, 2003

25. Nasierowska-Guttmejer A, Trzeciak L, Nowacki MP, et al: p53 protein accumulation and p53 gene mutation in colorectal cancer. Pathol Oncol Res 6:275-279, 2000

26. Risques RA, Moreno $V$, Ribas $M$, et al: Genetic pathways and genome-wide determinants of clinical outcome in colorectal cancer. Cancer Res 63:7206-7214, 2003

27. Forslund A, Kressner U, Lonnroth $C$, et al: p53 mutations in colorectal cancer assessed in both genomic DNA and cDNA as compared to the presence of p53 LOH. Int J Oncol 21:409415, 2002

28. Jansson A, Gentile M, Sun XF: p53 mutations are present in colorectal cancer with cytoplasmic p53 accumulation. Int J Cancer 92:338-341, 2001

29. Bouzourene H, Gervaz P, Cerottini JP, et al: p53 and Ki-ras as prognostic factors for Dukes' stage B colorectal cancer. Eur J Cancer 36:1008-1015, 2000

30. Tang $\mathrm{R}$, Wang PF, Wang $\mathrm{HC}$, et al: Mutations of p53 gene in human colorectal cancer: Distinct frameshifts among populations. Int $\mathrm{J}$ Cancer 91:863-868, 2001

31. Khan ZAJ, Jonas SK, Le-Marer $N$, et al: $p 53$ mutations in primary and metastatic tumours, and circulating tumour cells from colorectal carcinoma patients. Clin Cancer Res 6:3499-3504, 2000

32. Webley KM, Shorthouse AJ, Royds JA: Effect of mutation and conformation on the function of p53 in colorectal cancer. J Pathol 191:361-367, 2000

33. Bosari $S$, Viale $G$, Roncalli $M$, et al: p53 gene mutations, p53 protein accumulation and compartmentalization in colorectal adenocarcinoma. Am J Pathol 147:790-798, 1995
34. Cho Y, Gorina S, Jeffrey PD, et al: Crystal structure of a p53 tumor suppressor-DNA complex: Understanding tumorigenic mutations. Science 265:346-355, 1994

35. Cox DR: Regression models and life tables. J R Stat Soc 34:187-220, 1972

36. Graziano F, Cascinu S: Prognostic molecular markers for planning adjuvant chemotherapy trials in Dukes' B colorectal cancer patients: How much evidence is enough? Ann Oncol 14:10261038, 2003

37. Breivik J, Lothe RA, Meling Gl, et al: Different genetic pathways to proximal and distal colorectal cancer influenced by sex-related factors. Int J Cancer 74:664-669, 1997

38. Watatani M, Yoshida $T$, Kuroda $K$, et al: Allelic loss of chromosome 17p, mutation of the p53 gene, and microsatellite instability in rightand left-sided colorectal cancer. Cancer 77:16881693, 1996

39. Olschwang $S$, Hamelin R, Laurent-Puig $P$, et al: Alternative genetic pathways in colorecta carcinogenesis. Proc Natl Acad Sci U S A 94: 12122-12127, 1997

40. Lleonart ME, Garcia-Foncillas J, SanchezPrieto R, et al: Microsatellite instability and p53 mutations in sporadic right and left colon carcinoma: Different clinical and molecular implications. Cancer 83:889-895, 1998

41. West DW, Slattery ML, Robison LM, et al: Dietary intake and colon cancer: Sex- and anatomic site-specific associations. Am J Epidemiol 130:883-894, 1989

42. Meling $G I$, Lothe RA, Børresen $A-L$, et al: The TP53 tumour suppressor gene in colorecta carcinomas: I. Genetic alterations on chromosome 17. Br J Cancer 67:88-92, 1993

43. Kern SE, Fearon ER, Tersmette KW, et al: Clinical and pathological associations with allelic loss in colorectal carcinoma. JAMA 261:30993103, 1989

44. Kashkin KN, Nikolaev AV, Turbin DA, et al: Deletion of YNZ22 and ALU-VPA/MYCL1 loci in human colonic adenocarcinoma and postoperative prognosis. Mol Biol (Mosk) 35:798-804, 2001

45. Risio $M$, Casorzo $L$, Chiecchio $L$, et al: Deletions of $17 p$ are associated with transition from early to advanced colorectal cancer. Cancer Genet Cytogenet 147:44-49, 2003

46. Huang $C$, Taki $T$, Adachi $M$, et al: Mutations in exon 7 and 8 of p53 as poor prognostic factors in patients with non-small cell lung cancer. Oncogene 16:2469-2477, 1998
47. Vega FJ, Iniesta $P$, Caldes $T$, et al: p53 exon 5 mutations as a prognostic indicator of shortened survival in non-small-cell lung cancer. Br J Cancer 76:44-51, 1997

48. Kapiteijn E, Liefers GJ, Los LC, et al: Mechanisms of oncogenesis in colon versus rectal cancer. J Pathol 195:171-178, 2001

49. Nehls O, Klump B, Holzmann $K$, et al: Influence of p53 status on prognosis in preoperatively irradiated rectal carcinoma. Cancer 85 2541-2548, 1999

50. Diez M, Medrano M, Muguerza JM, et al: Influence of tumor localization on the prognostic value of P53 protein in colorectal adenocarcinomas. Anticancer Res 20:3907-3912, 2000

51. Rebischung C, Gerard JP, Gayet J, et al: Prognostic value of P53 mutations in rectal carcinoma. Int J Cancer 100:131-135, 2002

52. Bunz F, Hwang PM, Torrance $C$, et al: Disruption of p53 in human cancer cells alters the responses to therapeutic agents. J Clin Invest 104:263-269, 1999

53. Elsaleh $H$, Joseph D, Grieu F, et al: Association of tumour site and sex with survival benefit from adjuvant chemotherapy in colorectal cancer. Lancet 355:1745-1750, 2000

54. Fan S, el-Deiry WS, Bae I, et al: p53 gene mutations are associated with decreased sensitivity of human lymphoma cells to DNA damaging agents. Cancer Res 54:5824-5830, 1994

55. Mcllwrath AJ, Vasey PA, Ross GM, et al: Cell cycle arrests and radiosensitivity of human tumor cell lines: Dependence on wild-type p53 for radiosensitivity. Cancer Res 54:3718-3722, 1994

56. Bracey TS, Miller JC, Preece A, et al: Gamma-radiation-induced apoptosis in human colorectal adenoma and carcinoma cell lines can occur in the absence of wild type p53. Oncogene 10:2391-2396, 1995

57. Spitz FR, Giacco GG, Hess K, et al: p53 immunohistochemical staining predicts residua disease after chemoradiation in patients with high-risk rectal cancer. Clin Cancer Res 3:16851690, 1997

58. Luna-Perez $P$, Arriola EL, Cuadra $Y$, et al: p53 protein overexpression and response to induction chemoradiation therapy in patients with locally advanced rectal adenocarcinoma. Ann Surg Oncol 5:203-208, 1998

59. Wang $Y$, Jatkoe $T$, Zhang $Y$, et al: Gene expression profiles and molecular markers to predict recurrence of Dukes' B colon cancer. J Clin Oncol 22:1564-1571, 2004 